\title{
Maintenance of Serotonin in the Intestinal Mucosa and Ganglia of Mice that Lack the High-Affinity Serotonin Transporter: Abnormal Intestinal Motility and the Expression of Cation Transporters
}

\author{
Jason J. Chen, ${ }^{1}$ Zhishan Li, ${ }^{1}$ Hui Pan, ${ }^{1}$ Dennis L. Murphy, ${ }^{2}$ Hadassah Tamir, ${ }^{1,3}$ Hermann Koepsell, ${ }^{4}$ and \\ Michael D. Gershon 1 \\ ${ }^{1}$ Department of Anatomy and Cell Biology, Columbia University, College of Physicians and Surgeons, New York, New York \\ 10032, 2Laboratory of Clinical Science, National Institute of Mental Health, Bethesda, Maryland 20892, 3New York State \\ Psychiatric Institute, New York, New York 10032, and ${ }^{4}$ Anatomisches Institut der Bayerischen Julius-Maximilians- \\ Universitat, D-97070 Würzburg, Germany
}

\begin{abstract}
The enteric serotonin reuptake transporter (SERT) has been proposed to play a critical role in serotonergic neurotransmission and in the initiation of peristaltic and secretory reflexes. We analyzed potential compensatory mechanisms and enteric function in the bowels of mice with a targeted deletion of SERT. The guts of these animals were found to lack mRNA encoding SERT; moreover, high-affinity uptake of 5-HT into epithelial cells, mast cells, and enteric neurons was present in the SERT $+/+$ bowel but absent in the SERT -/ - bowel. However, both the SERT +/+ gut and the -/- gut expressed molecules capable of transporting 5-HT, but with affinities and selectivity much lower than those of SERT. These included the dopamine transporter (DAT) and polyspecific organic cation transporters OCT-1 and OCT-3. DAT and OCT immunoreactivities were present in both the submucosal and myenteric plexuses, and
\end{abstract}

the OCTs were also located in the mucosal epithelium. 5-HT was found in all of its normal sites in the SERT -/- bowel, which contained mRNA encoding tryptophan hydroxylase, but no $5-H T$ was present in the blood of SERT $-/-$ animals. Stool water and colon motility were increased in most SERT -/animals; however, the increase in motility (diarrhea) occasionally alternated irregularly with decreased motility (constipation). The watery diarrhea is probably attributable to the potentiation of serotonergic signaling in SERT -/- mice, whereas the transient constipation may be caused by episodes of enhanced 5-HT release leading to 5-HT receptor desensitization.

Key words: serotonin reuptake transporter; enteric nervous system; gastrointestinal motility; organic cation transporters; dopamine transporter; SERT knock-out mice
The gut is the only organ that manifests complex integrative behaviors and reflexes in the absence of input from the CNS (Trendelenburg, 1917; Furness and Costa, 1987; Gershon et al., 1994; Gershon, 1999). This ability is conferred on the bowel by its intrinsic innervation, the enteric nervous system (ENS) (Meissner, 1857; Auerbach, 1862; Bayliss and Starling, 1899; Bayliss and Starling, 1900a,b), which contains both the intrinsic primary afferent neurons and the interneurons (Bülbring et al., 1958; Kirchgessner et al., 1992, 1996; Kunze et al., 1995; Bertrand et al., 2000; Pan and Gershon, 2000). These cells enable the gut to detect and process sensory stimuli without extra-enteric assistance. Regulation of digestive activity by the ENS requires that it monitor the pressure and chemical content of the intestinal lumen; nevertheless, no nerves, intrinsic or extrinsic, penetrate the mucosal epithelium. Neuronal detection of luminal stimuli, therefore, is a trans-epithelial phenomenon. This process is mediated by subsets of enteroendocrine cells, which are specialized to act as sensory transducers (Kirchgessner et al., 1992; Grider et al., 1996, 1998; Pan and Gershon, 2000). These cells respond to luminal stimuli by releasing chemical transmitters that activate underlying pri-

\footnotetext{
Received Feb. 28, 2001; revised May 21, 2001; accepted May 16, 2001.

This work was supported by Grant NS12969 from the National Institute of Neurological Diseases and Stroke.

Correspondence should be addressed to Dr. Michael D. Gershon, Department of Anatomy and Cell Biology, Columbia University, College of Physicians and Surgeons, 630 West 168th Street, New York, NY 10032. E-mail: mdg4@columbia.edu. Copyright (ㄷ) 2001 Society for Neuroscience $0270-6474 / 01 / 216348-14 \$ 15.00 / 0$
}

mary afferent nerve fibers. The most well characterized of these sensory transmitters is serotonin (5-HT), which is produced and secreted by enterochromaffin (EC) cells (Erspamer, 1966; Vialli, 1966).

EC cells do not present a fixed target with which afferent nerve fibers can form a junction. All of the cells of the mucosal epithelium, including the EC cells, move because they are continuously replaced (Stappenbeck et al., 1998; Wong et al., 1999). New cells are generated in a stem cell zone in crypts and mature as they translocate to villus tips, in which they die and slough into the lumen. Epithelial cells also migrate to restore the integrity of the mucosal lining after injury (Heath, 1996). Replacement of EC cells is slower than that of enterocytes (Tsubouchi and Leblond, 1979), but the anatomical relationship between EC cells and primary afferent nerve fibers varies, and the distance between them is large (Wade and Westfall, 1985). EC cells thus signal by secreting massive amounts of 5-HT (Erspamer, 1966), which can be tolerated because 5 -HT is efficiently inactivated within the bowel (Wade et al., 1996; Chen et al., 1998).

Inactivation is critical for the termination of responses to 5-HT to prevent enteric 5-HT from exerting toxic effects on distant targets (Gershon and Ross, 1962) and from desensitizing its receptors (Chen et al., 1998). Mucosally released 5-HT is rapidly inactivated by reuptake into mucosal epithelial cells (Wade et al., 1996; Chen et al., 1998) mediated by a plasmalemmal 5-HT transporter serotonin reuptake transporter (SERT), the same molecule that is responsible for 5-HT reuptake into serotonergic 
neurons. Inhibition of mucosal SERT potentiates responses of intrinsic primary afferent neurons to the 5-HT secreted by EC cells and, if severe and prolonged, causes neuronal 5-HT receptors to desensitize (Chen et al., 1998; Pan and Gershon, 2000). Recently, mice that lack SERT activity have been generated by the targeted elimination of the second exon of the gene encoding SERT (Bengel et al., 1998). These mice survive well, although they are unable to take up 5-HT with high affinity and are insensitive to 3,4-methylenedioxymethamphetamine ("ecstasy"), a compound that releases 5-HT by a transporter-dependent mechanism. The current experiments were undertaken to investigate gastrointestinal function in mice that lack SERT and to determine whether compensatory mechanisms develop in these animals that permit them to inactivate 5 -HT released in the gut.

\section{MATERIALS AND METHODS}

Animals and tissue preparation. Mice lacking SERT (SERT -/- mice) were bred in the Laboratory of Clinical Science at the National Institute of Mental Health and transferred to Columbia University for analysis. In these animals, the second exon of the SERT gene has been replaced by homologous recombination with a phosphoglycerine kinase-neo gene cassette (Bengel et al., 1998). The backgrounds of the mice were CD-1 and $\mathrm{C} 57 \mathrm{BL} / 6 \mathrm{~J}$. Both strains were investigated, although no strain-related differences were found in any of the experiments. Control animals consisted of heterozygous and homozygous (wild-type) littermates of the mice that lacked SERT. Mice that lacked both SERT and the dopamine (DA) transporter (DAT) (Sora et al., 1998) were also investigated. These mice and their heterozygous and homozygous (wild-type) littermates were obtained from Dr. F. Scott Hall (National Institute on Drug Abuse, Bethesda, MD) and dissected in the laboratory of Dr. Courtney DeVries (Johns Hopkins University, Baltimore, MD). The gut was removed at Johns Hopkins University, fixed (see below), and transported to Columbia University for additional analysis. The backgrounds of the double knock-out mice lacking SERT and DAT were C57BL/6J.

For molecular and histological analyses, the mice were rapidly killed by cervical dislocation. This procedure was approved by the Animal Care and Use Committee of Columbia University. The small intestines and brains were removed from the animals. Small intestines were opened and cleaned. For physiological studies, segments of gut were placed in iced Krebs' solution and bubbled with a mixture of $95 \% \mathrm{O}_{2}-5 \% \mathrm{CO}_{2}$ until further investigated. For extraction of RNA, the tissue was transferred to an iced solution of Trizol (Life Technologies, Gaithersburg, MD). Brains were placed in Trizol for use as a positive control in studies of RNA.

Tissues to be examined by immunocytochemistry were fixed by immersion for $6-24 \mathrm{hr}$ with $4 \%$ formaldehyde (freshly prepared from paraformaldehyde) in $0.1 \mathrm{M}$ phosphate buffer, $\mathrm{pH} 7.5$, at $4^{\circ} \mathrm{C}$. After fixation, tissues were rinsed with PBS, cryoprotected overnight with $30 \%$ sucrose (w/v) in PBS at $4^{\circ} \mathrm{C}$, embedded in O.C.T. (Miles Inc., Elkhart, IN), and then stored at $-80^{\circ} \mathrm{C}$ until they were used. Sections were cut with a cryostat-microtome and thaw-mounted onto Superfrost/plus positively charged glass slides (Fisher Scientific, Pittsburgh, PA).

Reverse transcription-PCR. Specimens were homogenized in Trizol (1 $\mathrm{ml} / 100 \mathrm{mg}$ tissue). Chloroform (10\% of the total volume) was added, and the sample was covered, shaken vigorously, and placed on ice for $10 \mathrm{~min}$ before being subjected to centrifugation for $15 \mathrm{~min}(13,000 \times g)$. The aqueous phase was removed, and isopropanol (60\% of the Trizol volume) was used to precipitate the RNA. The RNA pellet was washed by resuspending it in $70 \%$ ethanol. The suspension was then centrifuged for 5 min $(10,000 \times g)$, dried, and redissolved in diethylpyrocarbonatetreated water. The extracted RNA $(2.5-3.0 \mu \mathrm{g})$ was used as a template for random hexamer-primed first strand cDNA synthesis catalyzed by Maloney murine leukemia virus reverse transcriptase (Life Technologies). One-tenth of the resulting cDNA from the original RNA was used for PCR amplification. Pairs of oligonucleotide primers were designed from the cDNA sequence of the mouse SERT (GenBank accession number Y08870; forward, 5'-CAA AAC CAA GAA CCA AGA G-3', for nucleotides 98-116; reverse, 5'-CAT AGC CAA TGA CAG ACA G-3', for nucleotides 454-436). Additional pairs of primers were used to detect cDNA encoding organic cation transporters (OCT) 1-3 (Busch et al., 1996b; Gründemann et al., 1998; Kekuda et al., 1998; Urakami et al., 1998; Wu et al., 1998) and tryptophan hydroxylase (Stoll and Goldman, 1991). The following primers were used: OCT-1 (GenBank accession number AB016257; forward, 5'-TCC ATG TTG CTC TTT CGC C-3', for nucleotides 638-656; reverse, 5'-TCA CAT TCA ACC AAT GCA GCT C-3', for nucleotides 1334-1313), OCT-2 (GenBank accession number AJ006036; forward, 5'-CCA GTG CAT GAG GTA TGA G-3', for nucleotides 353-371; reverse, 5'-CAG GAG CCC AAC AGT AAA G-3', for nucleotides 842-824), OCT-3 (GenBank accession number AF082566; forward, 5'-TGG AAG CCA CTA ATA CCA GC-3', for nucleotides 547-566; reverse, 5'-GGG ACC ACC CAG TAA TAG AG-3', for nucleotides 1114-1095), tryptophan hydroxylase (GenBank accession number J04758; forward, 5'-ATG AGA GAA TTT GCC AAG ACC-3', for nucleotides 1258-1278; reverse, 5'-CGT GAA CTA TAT TTC CCT CAG C-3', for nucleotides 1668-1647), and DAT (GenBank accession number AF109072; forward, 5'-GGT CAA GGA GCA GAA TGG AG-3', for nucleotides 179-198; reverse, 5'-CAA AAT ACT CAG CAG CGG G-3', for nucleotides 729-711). Twenty to 35 cycles of PCR amplification were performed as follows: $94^{\circ} \mathrm{C}$ for $1 \mathrm{~min}, 55^{\circ} \mathrm{C}$ for $50 \mathrm{sec}$, and $72^{\circ} \mathrm{C}$ for $40 \mathrm{sec}$. A PCR product of $\sim 357 \mathrm{bp}$ was obtained. To confirm the identity of the PCR product, it was cloned into a pCRII vector by using the TA-cloning kit (Invitrogen, San Diego, CA). Inserts in two individual clones were sequenced by the dideoxynucleotide-chain termination method (in the core facility of Columbia University). The sequence of the PCR product obtained from both brain and gut with the indicated primers was identical to that of the corresponding sequence in mouse SERT.

Assay of ${ }^{3} H-5-H T$ transport. To assay the uptake of 5-HT, the opened gut was pinned flat on a support of balsa wood. The preparations were then carried on their supporting frames through a succession of vials in Krebs' solution supplemented with L-ascorbic acid $(100 \mu \mathrm{M})$ and the monoamine oxidase $(\mathrm{MAO})$ inhibitor pargyline $(100 \mu \mathrm{M})$. The solutions were maintained at $37^{\circ} \mathrm{C}$ in an atmosphere of $95 \% \mathrm{O}_{2}-5 \% \mathrm{CO}_{2}$. The frames were cut in such a way that the flat sheets of tissue were exposed on both sides to the ambient medium. Preparations were equilibrated for $30 \mathrm{~min}$ and then transferred to a solution containing ${ }^{3} \mathrm{H}-5-\mathrm{HT}(20 \mathrm{nM})$ (DuPont NEN, Boston, MA). Specimens were incubated with ${ }^{3} \mathrm{H}-5-\mathrm{HT}$ for $30 \mathrm{~min}$. The uptake of ${ }^{3} \mathrm{H}-5-\mathrm{HT}$ was terminated by washing the tissues twice in $250 \mathrm{ml}$ of iced Krebs' solution in separate containers. Controls consisted of equivalent specimens incubated with ${ }^{3} \mathrm{H}-5-\mathrm{HT}$ for $30 \mathrm{~min}$ in solutions that lacked $\mathrm{Na}^{+}$(replaced isosmotically with choline chloride) or that contained the SERT antagonists fluoxetine $(10 \mu \mathrm{M})$ or chlorimipramine $(0.1 \mu \mathrm{M})$. Additional specimens were incubated with ${ }^{3} \mathrm{H}-5-\mathrm{HT}$ for $30 \mathrm{~min}$ in the presence of quinine $(10 \mu \mathrm{M})$ to inhibit OCT-1 (Busch et al., 1996b). To determine how much ${ }^{3} \mathrm{H}-5-\mathrm{HT}$ had entered intracellular compartments, ${ }^{3} \mathrm{H}-5-\mathrm{HT}$ was extracted with $70 \%$ ethanol (Gershon and Altman, 1971) and assayed by liquid scintillation spectrometry.

For radioautography, the specimens that had been exposed to ${ }^{3} \mathrm{H}-$ 5-HT were fixed overnight in a solution containing $2.5 \%$ glutaraldehyde in $0.1 \mathrm{M}$ phosphate buffer, $\mathrm{pH} 7.4$, at $4^{\circ} \mathrm{C}$, to which $3 \%$ sucrose was added to prevent the translocation of ${ }^{3} \mathrm{H}-5-\mathrm{HT}$ during fixation (Fischman and Gershon, 1964; Gershon and Ross, 1966b). The fixed preparations were washed, dehydrated through an ascending series of ethanols, cleared in propylene oxide, and embedded in an epoxy resin (Epon 812 ). Sections were cut at $1.0 \mu \mathrm{m}$ and mounted on slides that had been coated with chromium alum gelatin. The slides were ultimately layered with Ilford L4 photographic emulsion (Ilford, Paramus, NJ) by dipping in the melted emulsion. The emulsion-coated slides were exposed for 3 weeks at room

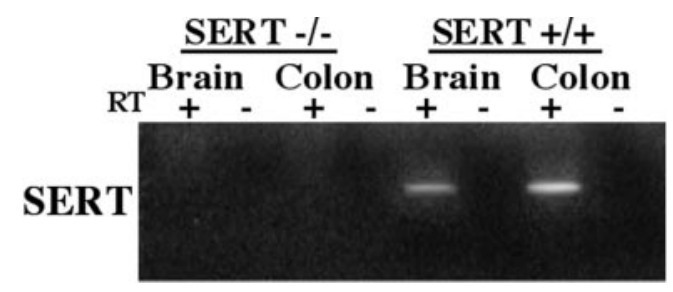

Figure 1. mRNA encoding SERT can be demonstrated in the murine gut by means of RT-PCR. The expected PCR product is $357 \mathrm{bp}$. mRNA encoding SERT is not found in the brains (positive control) or in the colons of SERT $-/-$ mice. In contrast, in wild-type (SERT $+/+$ ) mice, both the brain and colon contain mRNA encoding SERT. The lanes marked + illustrate the results obtained when RT was present. The lanes marked - were obtained when RT was absent (control indicating that the preparations were not contaminated with DNA). 


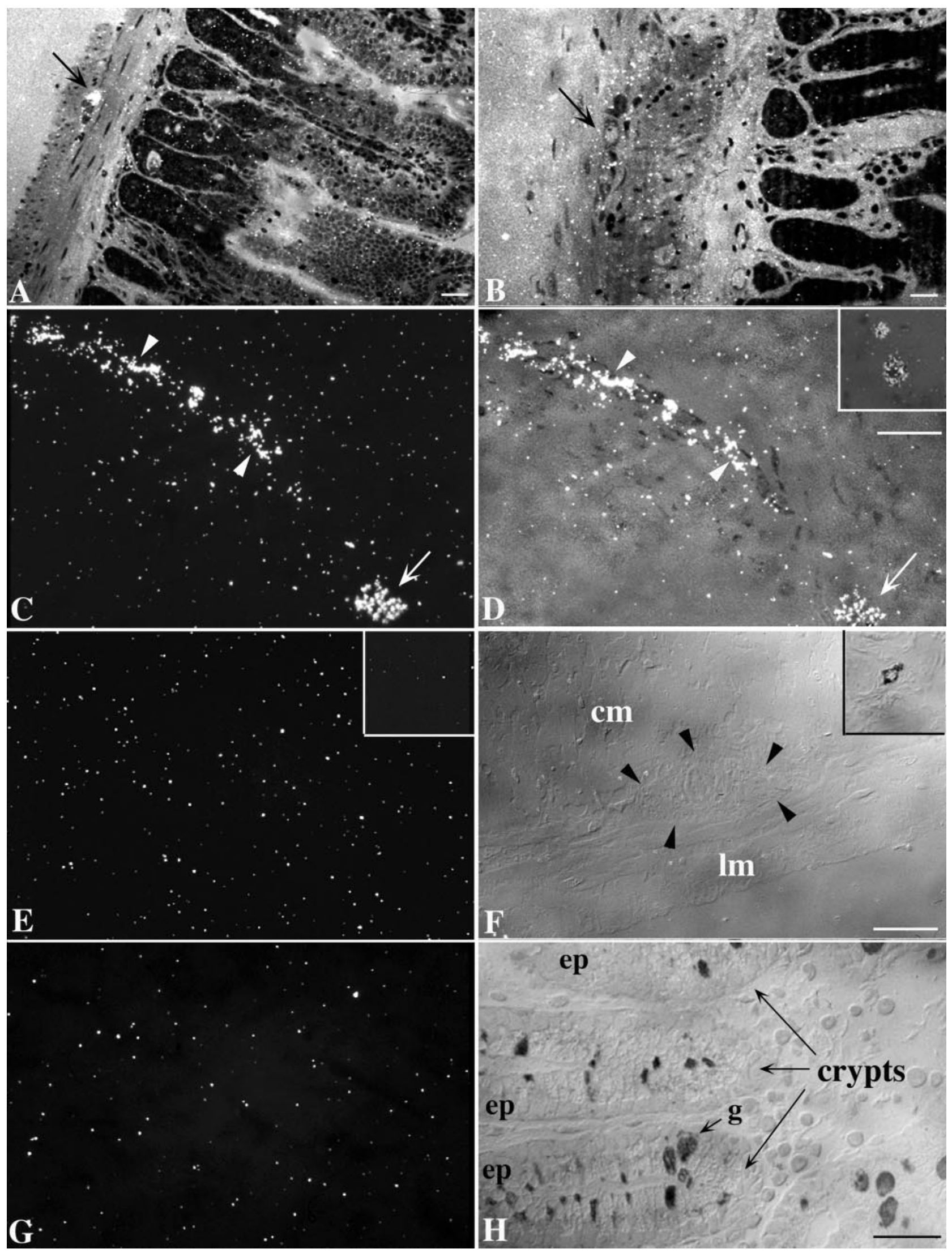

Figure 2. Radioautographic labeling of high-affinity ${ }^{3} \mathrm{H}-5-\mathrm{HT}$ uptake sites in the bowel wall of SERT $+/+$ and SERT $-/-$ mice. $A$, SERT $+/+$ small intestine. The arrow points to a myenteric ganglion labeled by ${ }^{3} \mathrm{H}-5-\mathrm{HT}$. Note the low level of labeling (but greater than that of background) present over the intestinal epithelium. $B$, SERT $+/+$ small intestine. Fluoxetine was present during incubation with ${ }^{3} \mathrm{H}-5-\mathrm{HT}$. The arrow points to a neuron in a myenteric ganglion. Neither the ganglion nor the epithelium is labeled by ${ }^{3} \mathrm{H}-5-\mathrm{HT}$. $C, D$, SERT $+/+$ colon. A tangential (Figure legend continues) 
temperature in an atmosphere of dry $100 \% \mathrm{CO}_{2}$. The specimens were then developed with a Kodak D19 developer (Eastman Kodak, Rochester, NY), fixed, washed, and counterstained with toluidine blue. Slides were examined microscopically using both bright-field and reflected dark-field illumination.

Immunocytochemistry. Primary antibodies generated against sequences found in the rat 5-HT transporter were generously donated by Dr. Randy D. Blakely (Department of Pharmacology, Vanderbilt University School of Medicine, Nashville, TN). These antibodies were used to attempt to immunostain the murine transporter in the adult and developing intestine. The same antibodies have been characterized previously and used to immunostain guinea pig SERT (Chen et al., 1998). Studies were also performed with rabbit polyclonal antibodies to OCT-1, DAT, DA, and 5-HT. The antibodies against OCT-1 have been characterized previously (Meyer-Wentrup et al., 1998; Karbach et al., 2000). Antibodies to DAT and DA (murine monoclonal) were obtained from Chemicon (Temecula, CA); antibodies to DA (polyclonal) and 5-HT were supplied by Incstar Corporation (Stillwater, MN). The antibodies were applied overnight in a humidified chamber at $4^{\circ} \mathrm{C}$ to fixed cryostat sections of gut. Preparations that were not exposed to primary antibodies were always processed simultaneously as routine controls. Secondary antibodies (diluted 1:200) (Vector Laboratories, Burlingame, CA) were labeled with biotin and visualized with avidin-Cy3 (Jackson ImmunoResearch, West Grove, PA).

Visualization of submucosal neurons activated by mucosal stimulation. Mice were killed as described above. The mucosa and submucosa were dissected from the circular muscle as an intact sheet of tissue $\sim 1.0 \mathrm{~cm}$ in length and pinned to silicone elastomer-coated dishes. Preparations were superfused with Krebs' solution that was oxygenated with a mixture of $95 \% \mathrm{O}_{2}$ and $5 \% \mathrm{CO}_{2}$. One half of each preparation was left unstimulated and served as the control, whereas the other half was subjected to experimental stimulation. Preparations were stimulated by stroking villus tips for $5 \mathrm{~min}$ in the oral to anal direction with a soft sponge. Activated neurons were visualized by stimulation in the presence of $\mathrm{N}$-(3-(triethylammoniumpropyl)-4-(4-dibutylamino)styryl)pyridinium dibromide (FM2-10) (100 $\mu \mathrm{M}$; Molecular Probes, Eugene, OR). The enteric neuronal uptake of FM2-10 in vitro is known to be stimulation dependent and thus prevented by the addition of tetrodotoxin $(0.5 \mu \mathrm{M})$ (Kirchgessner et al., 1996; Chen et al., 1998). Stimulated preparations were washed for 10-15 min with iced Krebs' solution. The mucosa was then removed, taking care to keep the tissue cold. Preparations were immediately examined by fluorescence microscopy (exciting filter bandpass, $530-560 \mathrm{~nm}$; dichroic mirror reflection short pass, $580 \mathrm{~nm}$; edge wavelength, $580 \mathrm{~nm}$ ). Neurons that had taken up FM2-10 were identified and counted in both the control and experimental halves of each preparation. In some controls, fluoxetine $(1.0 \mu \mathrm{M})$ was added to the superfusing solution $30 \mathrm{~min}$ before stimulation. Comparisons were made between the number of neurons activated in the control and experimental sides of each tissue.

Measurement of 5-HT. 5-HT was measured in the bowels (Kalivas and Miller, 1985) and blood (Anderson et al., 1981) of wild-type and SERT $-/-$ mice. Mice were killed as described above; blood was collected in 14 $\mathrm{ml}$ tubes, to which $1 \%$ EDTA $(1: 10 \mathrm{v} / \mathrm{v})$ was added. Sodium metabisulfite (50 $\mu \mathrm{l}$ of a $2 \%$ stock solution; to prevent oxidation) and $100 \mu \mathrm{l}$ of $3.4 \mathrm{M}$ perchloric acid (to precipitate protein) were added to $500 \mu \mathrm{l}$ of blood, vortex mixed, and placed on ice for $10-15 \mathrm{~min}$. The mixture was then centrifuged at $13,000 \times g$ for $10 \mathrm{~min}$. The resulting supernatant was transferred to fresh microcentrifuge tubes and stored at $-80^{\circ} \mathrm{C}$ until analysis. Segments of ileum or colon $(\sim 0.5 \mathrm{gm}$, wet weight $)$ were collected in $2 \mathrm{ml}$ of an isocratic mobile phase buffer [0.1 $\mathrm{M}$ trichloroacetic acid, $0.01 \mathrm{~m}$ sodium acetate, $0.01 \mathrm{~mm}$ EDTA, and $18 \%(\mathrm{v} / \mathrm{v})$ methanol] at a $\mathrm{pH}$ of 3.8. Two hundred microliters of $1 \%$ cysteine was added, and the tissues were immediately homogenized. The homogenate was then centrifuged at $11,000 \times g$ for $5 \mathrm{~min}$. The resulting supernatant was transferred to fresh microcentrifuge tubes and stored at $-80^{\circ} \mathrm{C}$. The supernatants from blood and gut were used for the assay of 5-HT and 5-hydroxyindole acetic acid by HPLC (Waters Associates, Milford, MA) with electrochemical detection (Tamir et al., 1994; Liu et al., 2000).

Colonic transit. The motility of the colon was evaluated in separate sets of control and SERT $-/-$ littermates. Animals were lightly anesthetized with ether, and a glass microbead (3 $\mathrm{mm}$ in diameter) was inserted through the anus and pushed, with a polished glass rod, into the colon for a distance of $2 \mathrm{~cm}$ (Osinki et al., 1999). The time from the completion of insertion to the expulsion of the bead was measured to the nearest 0.1 min to provide an estimate of the rate of transit in the colon.

\section{RESULTS}

\section{The gut of SERT -I- mice lacks mRNA encoding SERT}

Reverse transcription (RT)-PCR was used to analyze expression of SERT in $+/+,+/-$, and $-/-$ mice to confirm that the targeted deletion eliminates SERT expression in the gut, as well as in the brain. All of the animals were littermates. The brains of the mice were analyzed as a positive control. The PCR primers (see Materials and Methods) were designed on the basis of sequences present in the presumptively deleted second exon of the mouse gene that encodes SERT. mRNA was detected in the brains of SERT $+/+$ and $+/-$ animals but not in the brains of SERT $-/-$ mice (Fig. 1). Similarly, mRNA encoding SERT was detectable in the colons of SERT $+/+$ and $+/-$ animals but not in the colons of SERT $-/-$ mice.

\section{Enteric nerves take up ${ }^{3} \mathrm{H}-5-\mathrm{HT}$ in SERT $+/+$ but not in SERT -I- mice}

The uptake of ${ }^{3} \mathrm{H}-5$-HT in the gut was investigated in SERT +/+ and $-/-$ mice to determine whether there is a functional deficit in the gut of the knock-out animals that corresponds to their genetic abnormality. Radioautography was used so that the sites responsible for ${ }^{3} \mathrm{H}-5-\mathrm{HT}$ uptake in the bowel wall could be identified. The tissue was incubated for $30 \mathrm{~min}$ at $37^{\circ} \mathrm{C}$ with $20 \mathrm{~nm}$ ${ }^{3} \mathrm{H}-5-\mathrm{HT}$, a concentration that is below the measured $K_{\mathrm{m}}$ of enteric SERT (0.6-0.7 $\mu \mathrm{M})$ (Gershon and Altman, 1971; Chen et al., 1998). This concentration was selected to limit the uptake of ${ }^{3} \mathrm{H}-5-\mathrm{HT}$ to that mediated by a high-affinity transporter, such as SERT, or if there were to be one, a functionally similar molecule. After incubation, the tissue was washed and fixed. ${ }^{3} \mathrm{H}-5-\mathrm{HT}$ is retained and can be fixed in the bowel with glutaraldehyde, whereas radioactive metabolites wash out of the tissue and are not fixed (Gershon and Ross, 1966a,b). Radioautographic labeling, therefore, is attributable to the presence of ${ }^{3} \mathrm{H}-5-\mathrm{HT}$ itself. In SERT $+/+$ mice, ${ }^{3} \mathrm{H}-5-\mathrm{HT}$ was found to be taken up by axons of the myenteric plexus (Fig. $2 A, C, D$ ) and also by occasional myenteric nerve cell bodies (Fig. $2 C, D$ ). In addition, ${ }^{3} \mathrm{H}-5-\mathrm{HT}$ was taken up by epithelial cells (Fig. $2 A$ ) and by mast cells (Fig. $2 D$, inset). The degree of radioautographic labeling was far more

\section{$\leftarrow$}

section is cut through the intestinal muscle that includes an interganglionic connective (arrowheads) and a neuron (arrow) of the myenteric plexus. Note the intense labeling of both neural elements. The smooth muscle is not labeled and thus does not take up ${ }^{3} \mathrm{H}-5-\mathrm{HT}$. The same field has been visualized by means of incident (vertical) dark-field microscopy $(C)$ and with a combination of incident dark-field and transmitted bright-field microscopy $(D)$. $D$, Inset, A mast cell is double labeled with toluidine blue (to demonstrate metachromasia) and ${ }^{3} \mathrm{H}-5-\mathrm{HT}$. The cell was visualized as in $C$. $E, F$, SERT $-/-$ colon. Only a background level of labeling is evident. The same field has been visualized with a dark field $(E)$ and with interference contrast optics to show the unstained structures in the section $(F)$. The arrowheads in $F$ outline the location of a myenteric ganglion. $\mathrm{cm}$, Circular muscle; $l m$, longitudinal muscle. A mast cell is shown that is stained with toluidine blue $(F$, inset), but no radioautographic labeling can be detected in the corresponding dark field $(E$, inset). $G, H$, SERT $-/-$ colon. The section passes through the mucosa. No radioautographic labeling can be discerned. The section was photographed to show the same field in dark field $(G)$ and interference contrast views $(H)$. The locations of intestinal crypts, epithelia $(e p)$, and a goblet cell $(g)$ are indicated in $H$. Scale bars, $25 \mu \mathrm{m}$. The scale bars in $D, F$, and $H$ also apply to the corresponding dark-field images in $C, E$, and $G$. 


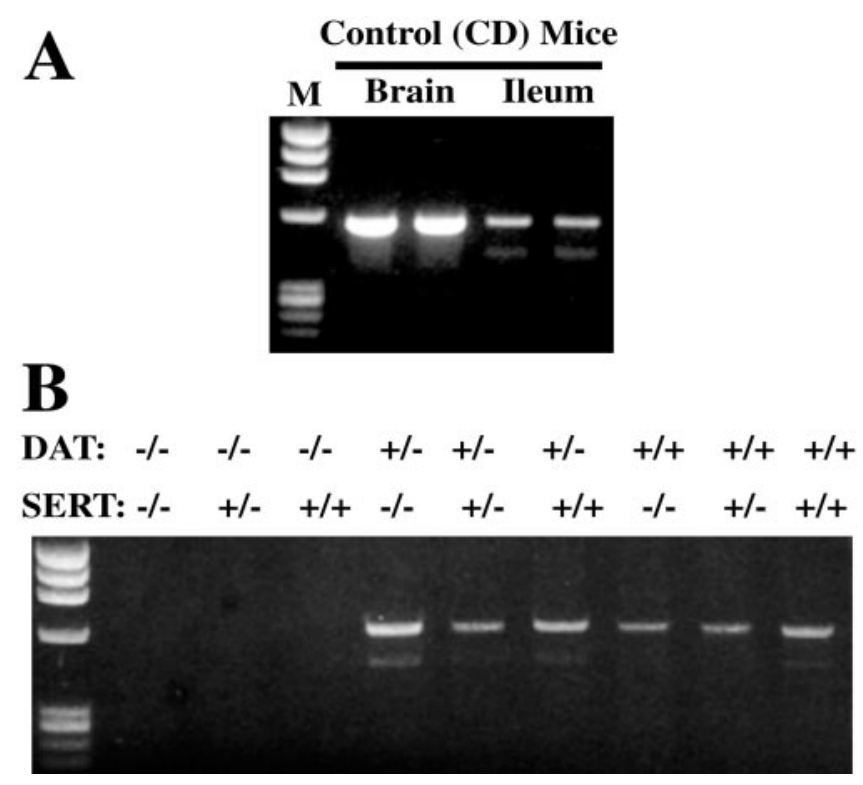

Figure 3. mRNA encoding DAT is present in the mouse gut and brain. The expected PCR product is 550 bp. $A$, Control mice. mRNA encoding DAT can be detected in the brain (positive control) and ileum. The smaller PCR product that is evident on gels lacks $132 \mathrm{bp}$ in the coding region and creates an in-frame deletion. $B$, mRNA encoding DAT is not detectable in the ileum of mice with a DAT $-/-$ genotype but is present in DAT $+/+$ and $+/-$ animals and is detectable in the bowels of mice lacking SERT.

intense in the neuronal elements and mast cells than in the epithelium. Mast cells, however, were infrequently encountered in tissue sections. No differences were noted in the pattern of labeling in small and large intestines. The uptake of ${ }^{3} \mathrm{H}-5-\mathrm{HT}$ was abolished by fluoxetine $(10 \mu \mathrm{M})$ (Fig. $2 B)$ but was not affected by the addition of quinine $(10 \mu \mathrm{M})$ (data not shown), an inhibitor of the polyspecific organic cation transporter OCT-1 (Busch et al., 1996b).

In contrast to the uptake of ${ }^{3} \mathrm{H}-5-\mathrm{HT}$ in the gut wall of SERT $+/+$ mice, no sites were observed under any conditions to become radioautographically labeled by ${ }^{3} \mathrm{H}-5-\mathrm{HT}$ in the bowels of SERT $-/-$ animals (Fig. $2 E-H$ ). Specifically, only a background density of silver grains was found in the SERT -/- gut over the myenteric plexus (Fig. 2, compare $E, F$ ), the epithelium (Fig. 2, compare $G, H$ ), or mast cells (Fig. 2, compare inset $E$, inset $F$ ). These observations confirm previous observations about the locations of ${ }^{3} \mathrm{H}-5-\mathrm{HT}$ uptake sites in the normal bowel wall (Gershon and Ross, 1966b; Wade et al., 1996) and indicate that high-affinity reuptake sites are completely lacking in SERT $-/-$ mice. These data, and the sensitivity of ${ }^{3} \mathrm{H}-5-\mathrm{HT}$ uptake to inhibition by fluoxetine and not by quinine, thus support the idea that highaffinity uptake of ${ }^{3} \mathrm{H}-5-\mathrm{HT}$ in the bowel wall is exclusively mediated by SERT.

\section{mRNA encoding DAT is present in the bowels of SERT -/- mice}

Because the SERT - /- mice are able to survive and eat relatively normally, we investigated the possibility that they might be able to express one or more other transporters that could at least partially compensate for the absence of SERT. Although the affinity of DAT for 5-HT is much less than that of SERT (Blakely et al., 1991; Giros et al., 1992; Chen et al., 1998), DAT can transport 5-HT if the 5-HT concentration is sufficiently high (Jackson and Wightman, 1995; Cases et al., 1998). The enteric expression of DAT was thus investigated by RT-PCR to determine whether DAT, which might be able to compensate for the absence of SERT, is expressed in SERT $-/-$ mice. The expression of DAT in the brains of the same animals was studied as a positive control. mRNA encoding DAT was detected in both the brains and ileum of wild-type (CD-1) mice (Fig. $3 A$ ). DAT expression was then studied in the intestines of SERT and DAT single and double knock-out animals. As expected, no mRNA encoding DAT was detected in the bowels of mice with a DAT $-/-$ genotype (Fig. $3 B$ ), confirming that the DAT gene expressed in the gut is identical to that cloned originally from the brain. However, mRNA encoding DAT was found in the intestines of SERT $-/-$ mice, as well as in those of SERT $+/+$ and $+/-$ animals. These data are consistent with the possibility that DAT expression in the SERT -/- bowel partially compensates in these animals for the absence of SERT. To do so, however, DAT would have to be expressed in sites that are proximate to those in which 5-HT is secreted.

\section{DAT immunoreactivity is present in the myenteric and submucosal plexuses}

Studies of dopamine metabolites and the sensitivity of enteric axons to the neurotoxin 6-hydroxydopamine first suggested that the murine bowel might contain dopaminergic neurons (Eaker et al., 1988). These observations, the presence of mRNA encoding DAT in the gut of SERT $+/+$ and SERT $-/-$ mice (Fig. 3), and the more recent demonstration that colonic motility is abnormally slow in DAT -/- mice (Walker et al., 2000) imply that DAT is likely to be expressed by enteric neurons in the mouse. If DAT were to be expressed by neurons and processes close to serotonergic nerve terminals, then 5-HT uptake into neurites that express DAT might be able to compensate in SERT -/- mice for the absence of SERT and limit the action of neuronally secreted 5-HT. Immunocytochemistry was thus used to locate sites of DAT expression in the bowels of SERT $+/+$ and SERT $-/-$ mice. DAT immunoreactivity was found in both the myenteric (Fig. $4 A, B$ ) and submucosal (Fig. $4 C, D$ ) plexuses of both SERT $+/+$ (Fig. $4 A, C$ ) and SERT -/- (Fig. 4B,D) mice. DATimmunoreactive neuronal perikaryal, as well as DATimmunoreactive neurites, were located in myenteric ganglia. Occasional neurites extended into the tertiary plexus (Fig. 4A,B). These observations are compatible with the possibility that DAT expressed in the myenteric and submucosal plexuses partially compensates in SERT $-/-$ mice for the absence of SERT. However, DAT immunoreactivity was not found in the mucosa (data not shown). Therefore, DAT might be able to mediate 5 -HT uptake in the ENS of SERT - /- mice, but it cannot compensate for the absence of SERT in the mucosa.

\section{mRNA encoding polyspecific organic cation transporters is expressed in the gut of wild-type and SERT $-I-$ mice}

Polyspecific OCT-1 was first isolated from a rat kidney library and was reported also to be expressed in the rat intestine and liver (Gründemann et al., 1994). OCT-1 has only 1/1000 the affinity of SERT for 5-HT, but it has a high capacity and is able to transport 5-HT and other monoamines across plasma membranes (Busch et al., 1996a). Therefore, we investigated the expression of OCT-1 in the brains and intestines of SERT $+/+$ and $-/-$ mice (Fig. $5 A-C)$. mRNA encoding OCT-1 was found in the colons but not in the brains of SERT $+/+$ mice, confirming that the expression of OCT-1 in mice is similar to that in rats (Gründemann et al., 1994). In contrast, mRNA encoding OCT-1 was present in both 


\section{Myenteric Plexus}

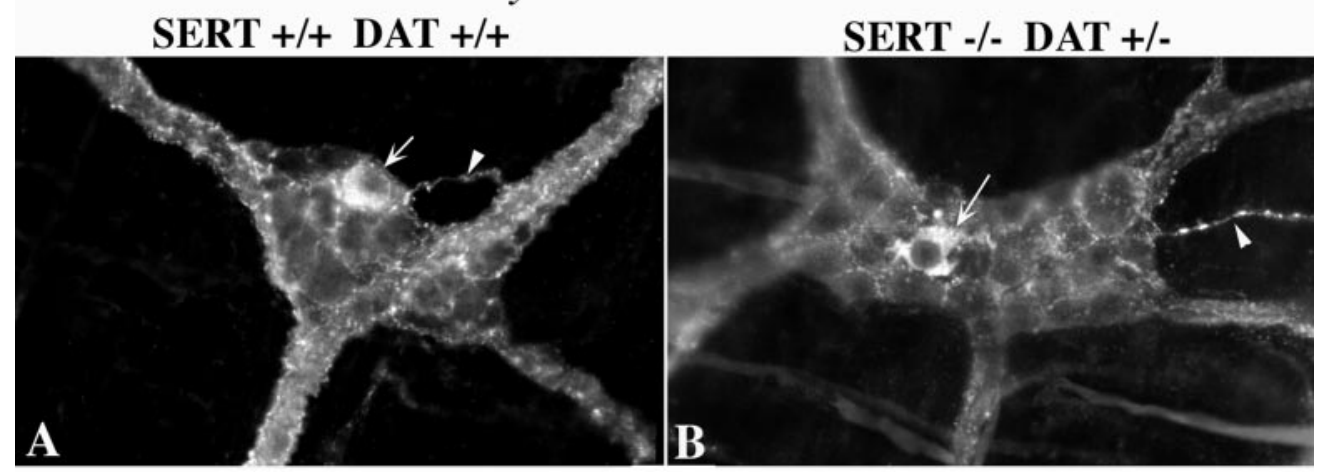

Submucosal Plexus
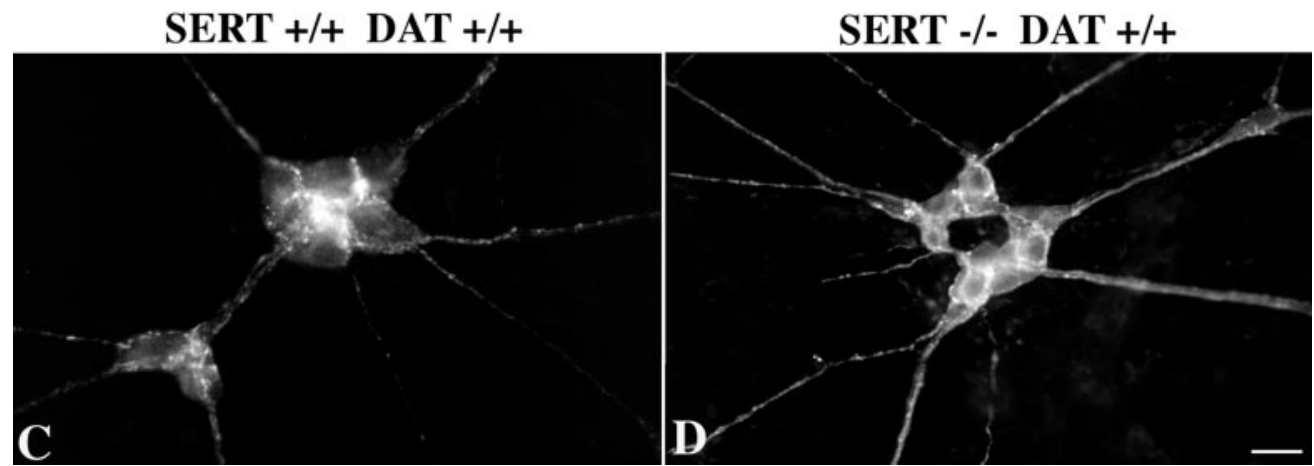

Figure 4. DAT immunoreactivity is present in the ENS of SERT $+/+$ and SERT $-/-$ mice. All four panels illustrate DAT immunoreactivity. $A$, Myenteric plexus of the colon of a mouse with a $+/+$ genotype for both SERT and DAT. $B$, Myenteric plexus of the colon of a mouse with a -/- genotype for SERT and a $+/-$ genotype for DAT. The arrows indicate the location of DAT-immunoreactive nerve cell bodies; the arrowheads indicate the location of neurites entering the tertiary plexus. $C$, Submucosal plexus of the small intestine of a mouse with a $+/+$ genotype for both SERT and DAT. $D$, Submucosal plexus of the small intestine of a mouse with a $-/-$ genotype for SERT and a $+/+$ genotype for DAT. the colons and the brains of the SERT $-/-$ animals. OCT- 1 was expressed in the small intestine, as well as the colon, and was present in SERT $+/+,+/-$, and $-/-$ mice (Fig. $5 B, C$ ). These data are consistent with the possibility that OCT-1 contributes to the inactivation of 5-HT when SERT is absent. The presence of mRNA encoding OCT-1 in the brains of SERT $-/-$ mice, when it is not present in the brains of $+/+$ animals, also suggests that the expression of OCT-1 is upregulated in the CNS when SERT is absent. Semiquantitative RT-PCR suggested that the expression of OCT-1 might be similarly upregulated in the small intestines but not in the colons of SERT $-/-$ mice.

OCT-3 is another polyspecific cation transporter that, similar to OCT-1, is capable of transporting 5-HT (Kekuda et al., 1998; Wu et al., 1998). Although OCT-3 is most abundantly expressed in the placenta, it has also been reported to be expressed in the intestine and the brain. In fact, OCT-3 has been demonstrated recently to be identical to the extraneuronal monoamine transporter (or uptake ${ }_{2}$ ), which was originally identified because of its ability to take up catecholamines (Iversen, 1967). As expected, mRNA encoding OCT-3 was detected in the small and large intestines of SERT $+/+$ mice and was also found in these organs in SERT $+/-$ and $-/-$ animals (Fig. $5 D$ ). The expression of OCT-1 (Fig. $5 C$ ) or OCT-3 (Fig. 5D) in the gut was not affected by the targeted deletion of DAT. In contrast to transcripts encoding OCT-1 and OCT-3, mRNA encoding OCT- 2 could not reproducibly be detected in the intestines of SERT $+/-$ or $-/-$ mice (data not shown). mRNA encoding OCT-2, however, was detected in the brains and kidneys of the same animals, suggesting that little OCT-2 is expressed in the bowel.

\section{SERT and OCT-1 proteins are expressed in the ENS}

SERT immunoreactivity has been demonstrated previously in the submucosal and myenteric plexuses of rats (Wade et al., 1996) and guinea pigs (Chen et al., 1998). We now report that SERT immunoreactivity is similarly present in the submucosal and myenteric plexuses of mice; it can be seen in both SERT $+/+$ (data not shown) and SERT $+/-$ animals (Fig. 6A,B). The distribution of SERT immunoreactivity in the ENS is similar to that of 5-HT (Costa et al., 1982; Furness and Costa, 1982) (see Fig. 9); SERT-immunoreactive axons are abundant in both plexuses, but nerve cell bodies are found only in the myenteric plexus. As in guinea pigs and rats (Wade et al., 1996; Chen et al., 1998), SERT immunoreactivity can also be found in the mucosal epithelia of mice (Fig. $7 A$ ). The distribution of SERT immunoreactivity in the murine mucosa is found throughout the crypt-villus axis (Fig. 7A). This distribution is similar to that of the guinea pig (Chen et al., 1998) but differs from that of mucosal SERT in the rat (Wade et al., 1996), in which it is primarily expressed only in intestinal crypts.

The immunoreactivity of OCT-1, similar to that of SERT, was found in both the submucosal (Fig. 6C,D) and myenteric (Fig. $6 E, F)$ plexuses. In contrast to SERT immunoreactivity, that of OCT-1 was observed in many nerve cell bodies in both plexuses. OCT-1-immunoreactive neuronal perikarya in the myenteric plexus, moreover, were far more abundant than those that displayed the immunoreactivities of SERT or 5-HT. The enteric distribution of OCT-1 immunoreactivity also resembled that of SERT in that it was located in the mucosal epithelium, as well as in nerves (Fig. $7 B, C$ ). The expression of OCT-1 immunoreactivity in SERT $+/+$ mice (Figs. $6 C, E, 7 B$ ) was indistinguishable from that seen in SERT $-/-$ animals (Figs. $6 D, F, 7 C$ ). The location of OCT-1 suggests that its ENS expression is not limited to serotonergic neurons and suggests that it is expressed by far more neurons than is SERT. OCT- 1 , however, is present in locations in which it would have access to 5-HT secreted by either axon terminals within the enteric plexuses or EC cells of the intestinal mucosa. 

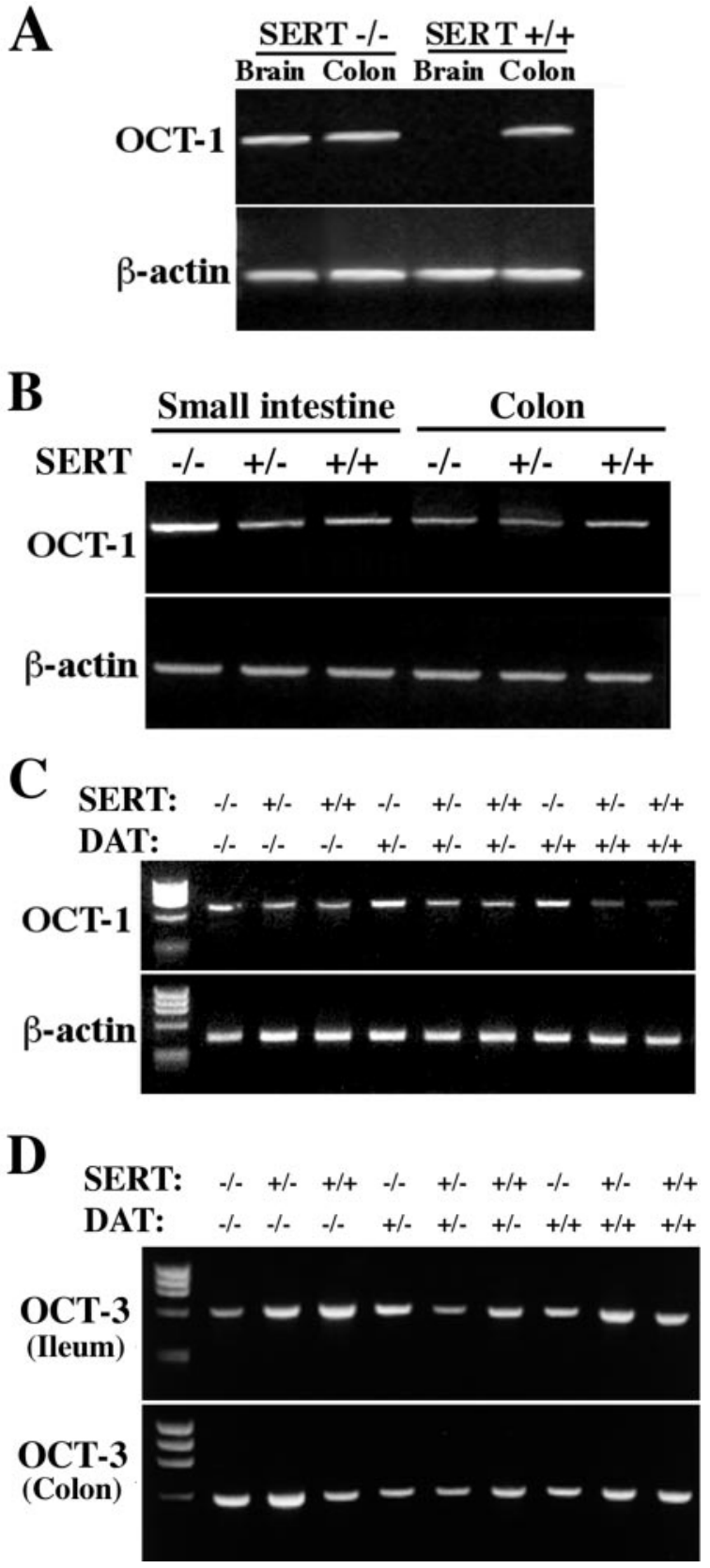

Figure 5. mRNA encoding OCT-1 and OCT-3 can be demonstrated in the murine gut by means of RT-PCR. The expected PCR products are $697 \mathrm{bp}$ for OCT-1 and 568 bp for OCT-3. A, mRNA encoding OCT-1 is found in both the brains and colons of SERT $-/-$ mice. In contrast, only the colon and not the brain contains mRNA encoding OCT-1 in wild-type (SERT $+/+$ ) mice. mRNA encoding $\beta$-actin was simultaneously demonstrated by RT-PCR. $B$, mRNA encoding OCT-1 is found in both the small intestines and the colons of SERT $+/+,+/-$, and $-/-$ mice. Expression of OCT- 1 appears to be greater relative to that of $\beta$-actin in the small intestines of SERT $-/-$ mice compared with the small intestines of SERT $+/-$ or $+/+$ mice. A similar apparent upregulation of OCT-1 is not seen in the SERT $-/-$ colon. $C$, mRNA encoding OCT-1 appears to be upregulated in the small intestines of SERT - /- mice, but the knock-out of DAT does not appear to affect the expression of OCT-1. D, mRNA encoding OCT-3 is found in both the small intestines and the colons of SERT $+/+,+/-$, and $-/-$ mice. The knock-out of DAT does not affect the expression of OCT-3.
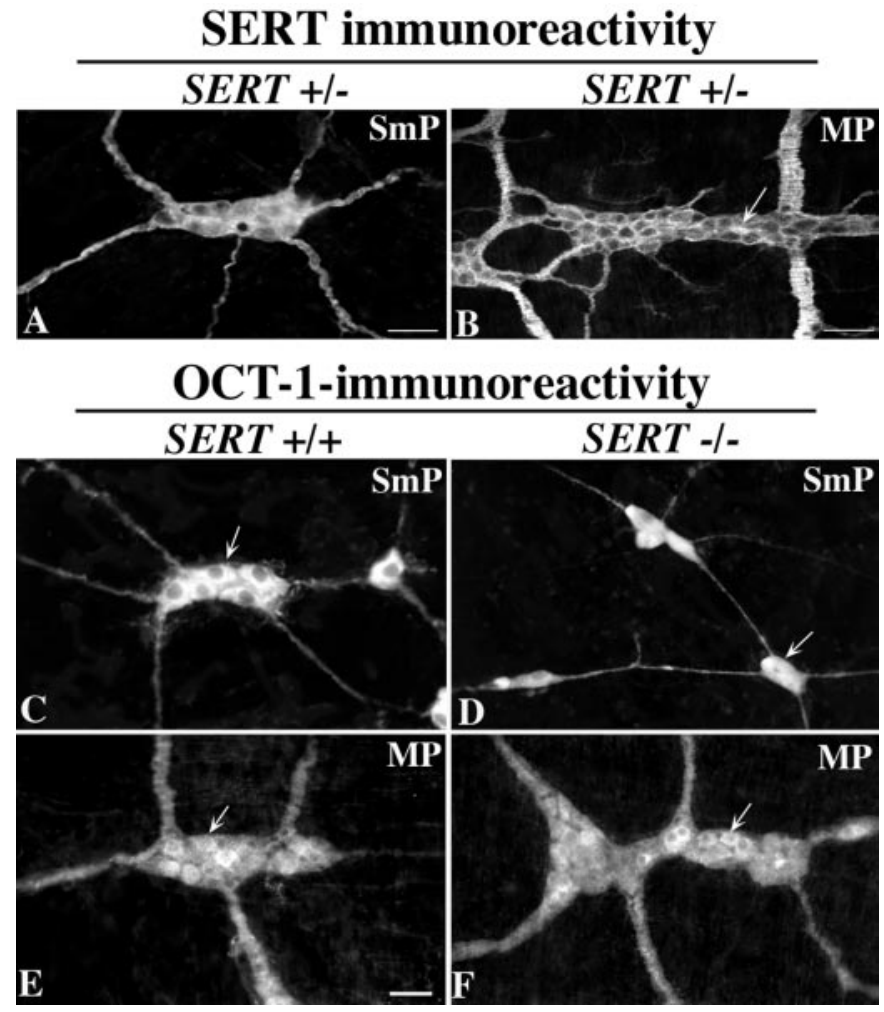

Figure 6. SERT and OCT-1 immunoreactivities are found in both the submucosal and myenteric plexuses. $A, B$, SERT immunoreactivity. Scale bars, $50 \mu \mathrm{m}$. $C-F$, OCT-1 immunoreactivity. Scale bar, $50 \mu \mathrm{m}$. SERT immunoreactivity is abundant in the neurites of the neuropil of both the submucosal $(A)$ and myenteric $(B)$ plexuses of a SERT $+/-$ mouse. Only the myenteric plexus contains SERT-immunoreactive nerve cell bodies (arrow). OCT-1-immunoreactive nerve cell bodies (arrows) are abundant in both the submucosal $(C, E)$ and myenteric $(D, F)$ plexuses of SERT $+/+$ and SERT $-/-$ mice.

The blood, but not the bowel, is depleted of 5-HT in SERT $-/-$ mice

The 5-HT levels of the blood and intestines of SERT $-/-$ mice were determined and compared with those of their SERT +/+ littermates. 5-HT was measured in whole blood so as to include the stores within both platelets and plasma. Surprisingly, although the 5-HT level of whole blood was substantial in SERT $+/+$ mice, virtually no 5-HT could be detected in the blood of the SERT $-/-$ littermates of the same animals (Fig. $8 A$ ). In contrast to the blood, 5-HT levels in the intestines of the SERT $-/-$ mice were not significantly different from those of the SERT +/+ animals (Fig. 8B). These data suggest that SERT biosynthesis or reuptake, mediated by an alternative transporter, can compensate for the loss of the SERT-mediated ability to retrieve secreted 5 -HT in the gut of SERT $-/-$ animals. In contrast, platelets, which do not synthesize 5-HT, are totally dependent on uptake to obtain 5-HT (Erspamer, 1966). Platelets thus do not appear to express a transporter other than SERT that can compensate for the absence of SERT in their plasma membrane. The virtual absence of 5-HT from the blood of SERT $-/-$ mice suggests that plasma 5-HT is negligible when platelets do not take up or contain 5-HT. The overflow of 5-HT secreted from the bowel must therefore be removed, despite the absence of SERT in the knock-out mice, before reaching the systemic circulation. 


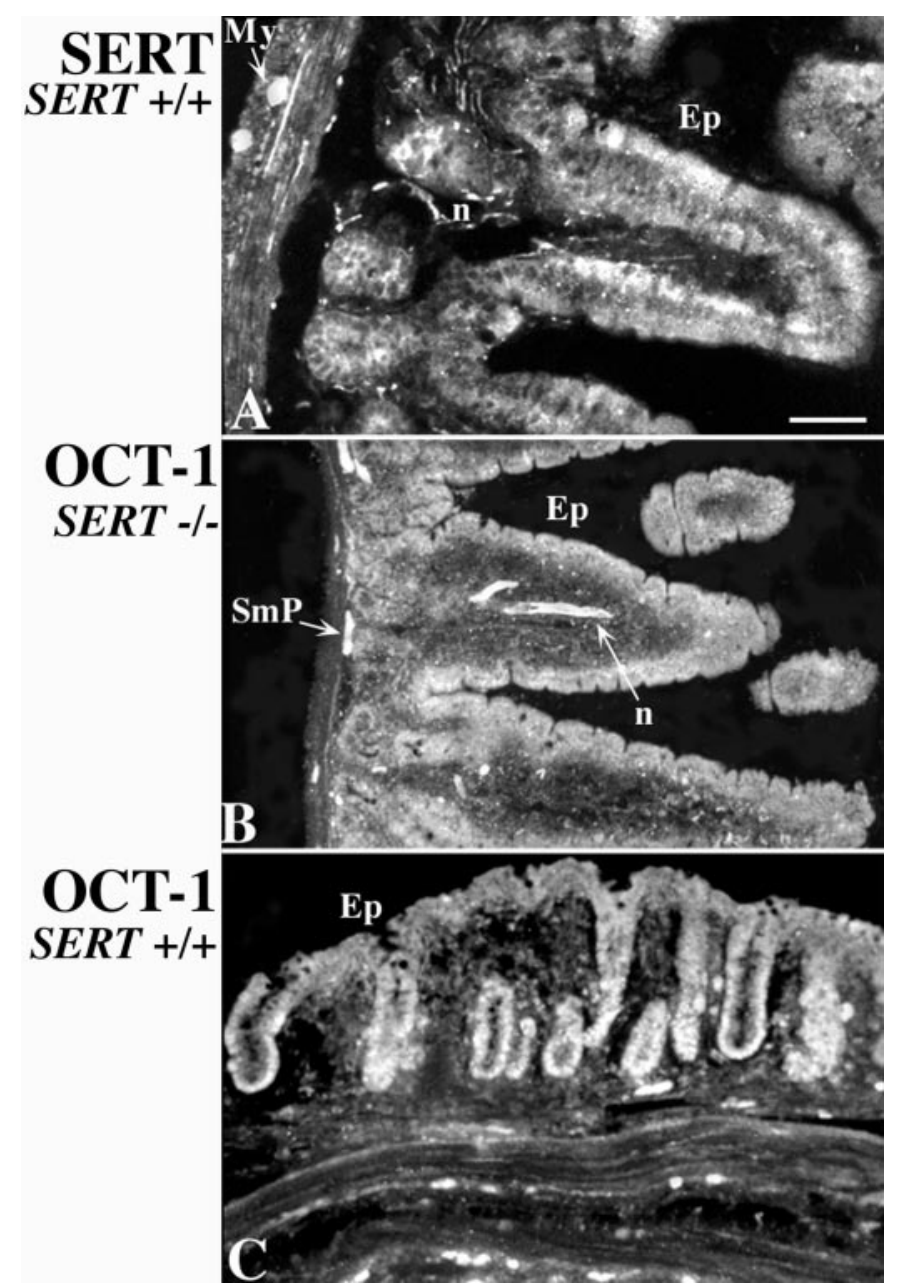

Figure 7. The enteric distributions of SERT and OCT-1 immunoreactivities are similar but not identical. Sections of mouse intestine were obtained with a cryostat-microtome and immunostained with antibodies to SERT $(A)$ or OCT-1 $(B, C)$. $A$, SERT immunoreactivity in the SERT $+/+$ small intestine; note the presence of SERT immunoreactivity in the mucosal epithelium $(E p)$, as well as in nerves $(n)$. Neuronal perikarya can be found in myenteric $(M y)$ but not submucosal ganglia. B, OCT-1 immunoreactivity in the SERT $-/-$ small intestine. OCT-1 immunoreactivity is present in the mucosal epithelium $(E p)$, as well as in the ENS. In contrast to the immunoreactivity of SERT, that of OCT-1 is also present in neurons of the submucosal plexus $(\operatorname{SmP})$. OCT-1-immunoreactive bundles of nerve fibers are prominent in the mucosa $(n)$. $C$, OCT-1 immunoreactivity in the SERT +/+ colon. In the colon, as in the small intestine, OCT-1 immunoreactivity is present in both the epithelium $(E p)$ and nerves. Note that OCT-1 immunoreactivity is found in nerve fibers within the thick colonic circular muscle. Scale bar: $A-C, 50 \mu \mathrm{m}$.

\section{5-HT immunoreactivity is present in enteric nerves of SERT -I- mice}

Immunocytochemical studies were performed to locate 5-HT immunoreactivity in the ENS of SERT $-/-$ mice. Although tryptophan hydroxylase has been reported to be present in the ENS (Yu et al., 1999), some investigators have suggested that enteric neurons do not synthesize 5-HT but obtain it exclusively through SERT-mediated uptake (Costa et al., 1996; Sang and Young, 1996). This idea is based on the reports from several investigators that enteric neurons must be preloaded with an exogenous amine (5-HT or 5,7-dihydroxytryptamine) that reacts with antibodies to 5-HT to demonstrate their 5-HT immunoreactivity (Costa et al., 1982). If enteric neurons do depend on the

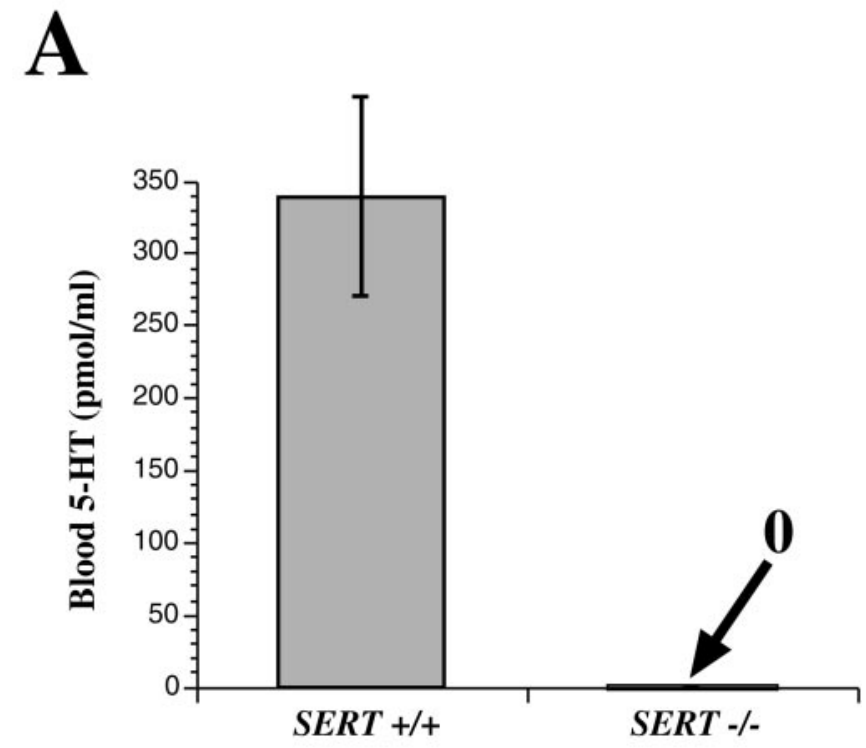

B $\square S E R T+/+\square S E R T$-/-

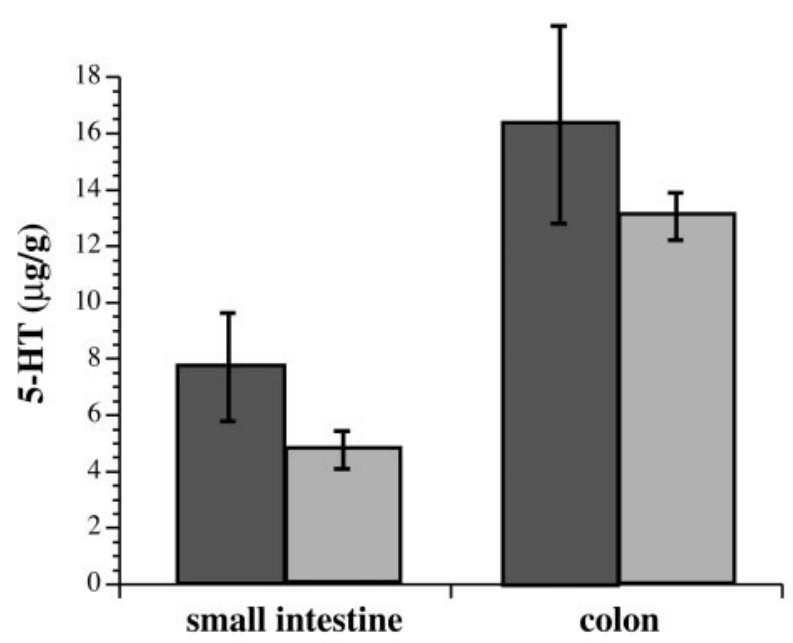

Figure 8. 5-HT levels are depleted in the blood but not in the gut of SERT $-/-$ mice. $A$, Whole-blood 5-HT, measured by HPLC with electrochemical detection, in the blood of SERT $+/+$ and SERT $-/-$ mice. Note that the amount of 5 -HT in the blood of SERT $-/-$ mice is below the level of sensitivity of the technique $(\sim 1 \mathrm{pmol} / \mathrm{ml}) . B$, The $5-\mathrm{HT}$ content of the full thickness of the bowel wall was measured in the small intestines and colons of SERT $+/+$ and SERT $-/-$ mice. The tissue 5 -HT concentration is higher in the colon than in small intestine in both types of mice $(p<0.01)$; however, in neither region of the gut is there a significant difference between SERT $+/+$ and SERT $-/-$ mice in the level of enteric 5-HT.

activity of SERT to obtain 5-HT, no 5-HT would be expected to be present in enteric neurons of SERT -/- mice. Enteric neurons would be predicted to behave just as do blood platelets (see above). In the current experiments, 5-HT immunoreactivity was found to be readily demonstrable in the ENS of both SERT $+/+$ and SERT $-/-$ mice (Fig. 9). In fact, the appearance of 5-HT immunoreactivity in both the myenteric [Fig. 9, compare $A$ and $C$ $($ SERT $+/+)$ with $B$ and $D$ (SERT - $/-)$ ] and the submucosal plexus could not be distinguished in the two types of mice. However, the appearance of the 5-HT-immunoreactive neurites 


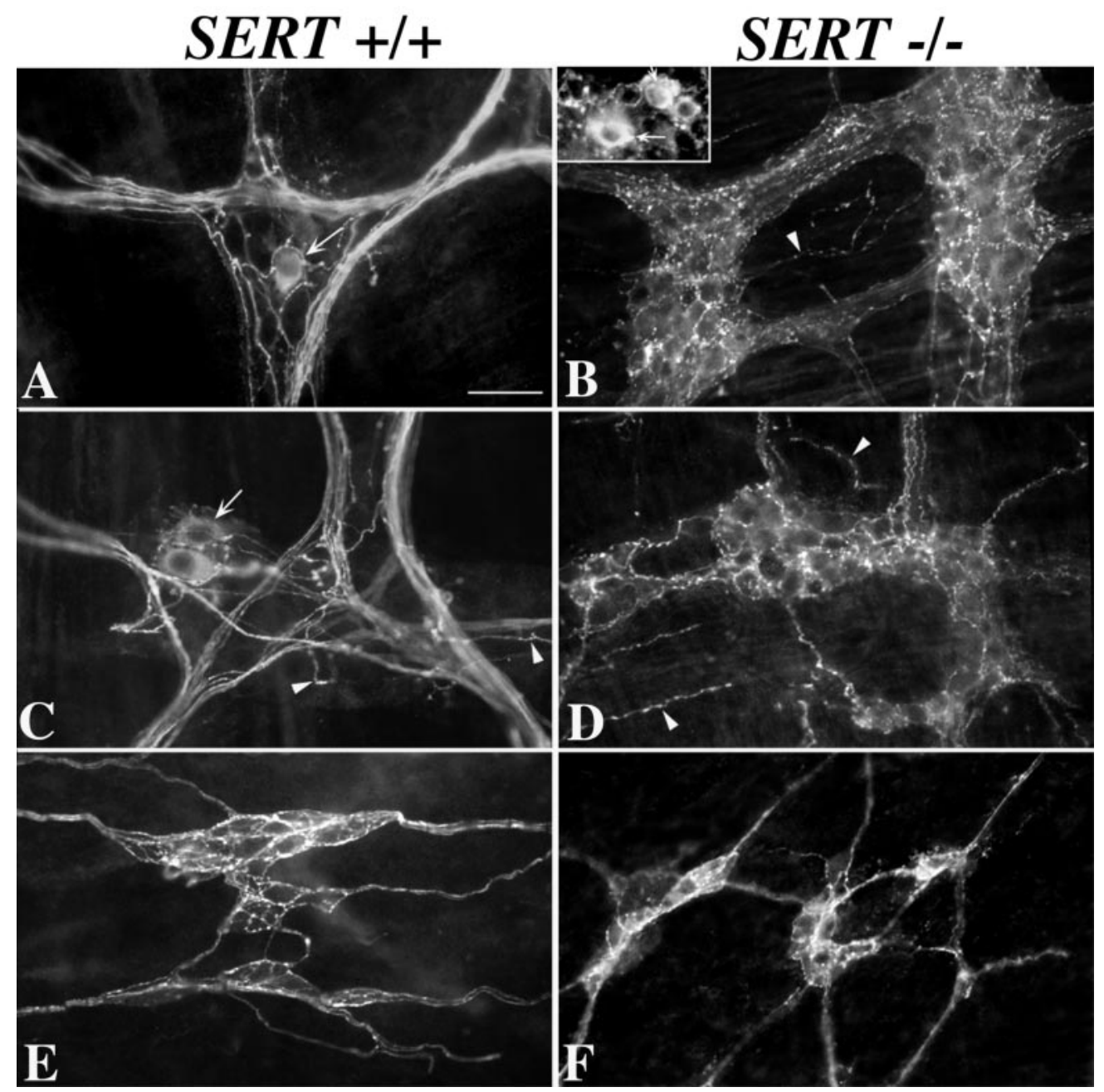

Figure 9. 5-HT immunoreactivity is present in the ENS of both SERT +/+ and SERT $-/-$ mice. 5-HT immunoreactivity was demonstrated in laminar preparations of the bowel wall containing either the myenteric or submucosal plexus without preloading the tissue with an exogenous 5-HT-immunoreactive molecule or otherwise amplifying the endogenous 5-HT content of the bowel. Tissue was kept on ice during dissection and fixed immediately thereafter to minimize the potential for postmortem 5-HT uptake. Preparations from SERT $+/+$ mice are illustrated in $A, C$, and $E$. Preparations from SERT $-/-$ mice are illustrated in $B, D$, and $F$. $A, B$, Stomach. $C$, Colon. $D$, Ileum. $E, F$, Colon. The locations of nerve cell bodies are indicated by the arrows $[A, B$ (inset), C]. The locations of neurites in the tertiary plexus are indicated by $a r$ rowheads $(B-D)$.

was not identical in SERT $+/+$ and SERT $-/-$ mice. The 5-HT-immunoreactive varicose terminal axons in myenteric ganglia were far more abundant in the SERT $-/-$ animals than in SERT $+/+$ mice. In contrast, there were fewer coarse nonvaricose tracts running through the myenteric ganglia in SERT -/mice than in their SERT +/+ littermates. The tertiary plexus also contained 5-HT-immunoreactive varicose neurites in both SERT $+/+$ and SERT $-/-$ mice; however, the 5-HT-immunoreactive axons of the tertiary plexus were more abundant in SERT -/mice. The 5-HT-immunoreactive neurites in the submucosal plexus in both SERT $+/+$ (Fig. 9E) and SERT $-/-$ (Fig. 9F) mice were mainly varicose terminal axons; no consistent morphological differences were detected in 5-HT-immunoreactive elements of the submucosal plexus in the two types of mice. 5-HTimmunoreactive nerve cell bodies were observed in the myenteric plexuses of both SERT $+/+$ (Fig. 9 $A, C$ ) and SERT $-/-$ (Fig. 9B) mice, but no significant differences were found in either their numbers or their appearance in the two types of mice. In the SERT $+/+$ or the SERT $-/-$ mice, it was not necessary to preload the tissue with an exogenous amine to visualize 5-HTimmunoreactive neurons and neurites.

\section{mRNA encoding tryptophan hydroxylase is present in the gut of mice lacking SERT, DAT, or both SERT and DAT}

SERT $-/-$ and DAT $-/-$ mice were bred to obtain double knock-out animals that lacked both transporters. The DAT -/- mice were of interest because the motility of the colon has been found to be abnormally slow in these animals (Walker et al., 2000). Expression of mRNA encoding tryptophan hydroxylase was investigated in the bowels of the resulting animals by RTPCR. The genotypes of the mice examined and their corresponding expression of tryptophan hydroxylase are presented in Figure 10. Brains were investigated as a positive control. RT-PCR was made semiquantitative by using the relative expression of $\beta$-actin as an internal standard. mRNA encoding tryptophan hydroxylase was detected in the bowels of all of the animals, regardless of their SERT or DAT genotype; however, an apparent upregulation of mRNA encoding tryptophan hydroxylase was observed in each of the SERT -/- mice, regardless of their DAT genotype (Fig. 10). These observations confirm that 5-HT can be synthesized in the bowels of SERT $-/-$ mice and are compatible with the possibility that the expression of tryptophan hydroxylase is upregulated to compensate for the loss of the SERT-mediated ability of cells to take up 5-HT. In contrast, the enteric expression of tryptophan hydroxylase appears to be independent of that of DAT.

\section{Rectal motility is altered in SERT -/ - mice}

Stool weight and water content were measured in SERT $+/+$ and $-/-$ mice and compared. Littermates of each genotype were used in the study and were examined without regard to sex. The animals were closely matched in terms of body weight (Fig. 11 $A$ ); however, the wet weight of the stool collected over a period of 24 


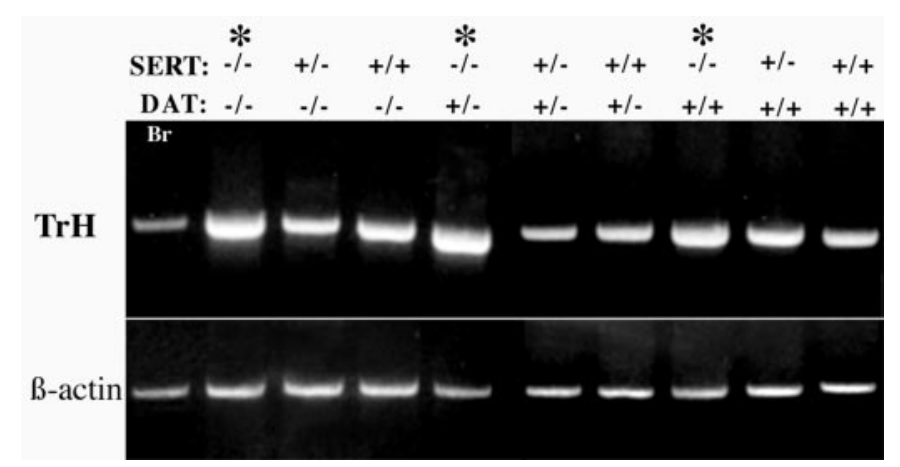

Figure 10. mRNA encoding tryptophan hydroxylase $(\operatorname{Tr} H)$ was detected in the intestines of the offspring of SERT and DAT knock-out mice. The expected PCR product is $410 \mathrm{bp}$. The expression of tryptophan hydroxylase was investigated by semiquantitative RT-PCR in the bowels of mice lacking SERT, DAT, or both SERT and DAT. The brains of wild-type mice were also studied as a positive control. The SERT and DAT genotypes of the mice that were examined are listed above the lanes in the gels illustrating the corresponding PCR products. Note that there is an apparent increase in tryptophan hydroxylase expression in all of the animals with a SERT $-/$ - genotype (*), but that the level of expression of tryptophan hydroxylase is independent of the DAT genotype of the animals.

hr was significantly greater in SERT $-/-$ mice compared with their SERT $+/+$ littermates $(p<0.001)$. The increased wet weight of the stool of the SERT $-/-$ mice was attributable to a significant increase in stool water $(p<0.001)$ (Fig. 11A). The motility of the distal colon and rectum was assessed to test the hypothesis that stool water is increased in SERT $-/-$ mice because an excessively rapid rate of stool transit in these animals provides inadequate time for normal water resorption in their large intestine. Expulsion of glass beads from the rectum was used to evaluate motility. The beads were inserted into the colon at a uniform distance of $2 \mathrm{~cm}$ from the anal verge. The time to expulsion was then measured for each SERT $+/+$ or $-/-$ mouse individually. These times were plotted as a histogram (Fig. $11 B, C)$. The time required for the beads to be expelled was shorter in most of the SERT $-/-$ mice than in their SERT $+/+$ littermates; however, in a small subset of SERT - / - individuals, the time to expulsion was actually greater than that of any of the SERT $+/+$ animals. The longest time a SERT $+/+$ mouse took to expel the bead was $\sim 350 \mathrm{~min}$ (Fig. $11 \mathrm{~B}$ ), whereas some SERT $-/-$ animals required $425-550 \mathrm{~min}$ (Fig. $11 C$ ). The $\mathrm{z}$ scores for the expulsion times showed that they were normally distributed in SERT +/+ mice; all scores fell within \pm 2 SDs of the mean (Fig. $11 B$ ). In contrast, the $\mathrm{z}$ scores showed that the distribution of expulsion times was highly skewed in the SERT $-/-$ animals (Fig. 11C); the bulk of the times were faster than the mean, but a small number were slower, and some were much slower $(>2$ SDs greater than the mean). These observations suggest that the motility of the colon and rectum is increased in most SERT -/mice but decreased in a small subset of these mice. The SERT $-/-$ animals can thus be divided into a larger group with diarrhea ( $\sim 75 \%$ of the animals; bead expulsion times below the lower $95 \%$ confidence limit of the SERT $+/+$ mean) and a smaller remaining group with constipation (Fig. 11D) (bead expulsion times above the upper $95 \%$ confidence limit of the SERT $+/+$ mean). The colorectal motility of the SERT $-/-$ mice with diarrhea was significantly faster than that of their SERT $+/+$ littermates $(p<$ $0.001)$. In contrast, the motility of the colon and rectum of the small subset of constipated SERT $-/-$ mice was significantly slower than that of either their SERT $+/+$ littermates $(p<$ $0.002)$ or the SERT $-/-$ mice with diarrhea $(p<0.001)$. When rectal motility of individual SERT $-/-$ animals was measured at weekly intervals, the glass bead expulsion times were found to change so that animals that were constipated when first examined developed diarrhea and mice with diarrhea became constipated (data not shown).

\section{DISCUSSION}

The local SERT-mediated uptake of 5-HT has been postulated to be responsible for terminating serotonergic signal transmission from EC cells to primary afferent nerves in the mucosa and neurotransmission in the enteric plexuses (Wade et al., 1996; Chen et al., 1998; Pan and Gershon, 2000). SERT-mediated reuptake also appears to inactivate 5-HT (Hoffman et al., 1991), which is secreted by the mast cells of mice during immune responses (Gershon et al., 1975; Askenase et al., 1980; Tamir et al., 1982; Askenase et al., 1983). We have confirmed by RT-PCR that the intestines of SERT $-/-$ mice lack mRNA encoding SERT. The targeted deletion of the second exon of the gene encoding SERT, therefore, prevents the expression of SERT in the gut, as well as in the brain (Bengel et al., 1998). In addition, radioautographic studies with ${ }^{3} \mathrm{H}-5-\mathrm{HT}$ indicated that the highaffinity uptake of 5 -HT in the bowels of SERT $-/-$ mice is deficient in epithelial cells, mast cells, and nerve fibers. In the face of these defects, enteric serotonergic signaling would be expected to be abnormal in these animals. Because free 5-HT is sufficiently toxic enough to mediate anaphylactic shock in mice (Gershon and Ross, 1962), its release from the large EC cell 5-HT pool in SERT $-/-$ animals might even be lethal.

SERT - / - mice gain weight and survive well (Bengel et al., 1998; Rioux et al., 1999; Fabre et al., 2000). Regardless of whether or not the physiology of the SERT -/- gut is normal, the bowel must function well enough to support life; therefore, neither peristaltic (Kirchgessner et al., 1992, 1996; Foxx-Orenstein et al., 1995; Grider et al., 1996, 1998; Jin et al., 1999; Pan and Gershon, 2000) nor secretory (Sidhu and Cooke, 1995; Cooke et al., 1997) reflexes, both of which are thought to be initiated by 5-HT, can be absent. Conceivably, these reflexes persist in SERT-deficient mice because 5 -HT is inactivated by means that do not involve SERT. Alternatively, transmitters other than 5-HT might mediate the reflexes in SERT $-/-$ animals.

MAO (MAO-A, MAO-B) and all of the other enzymes that catabolize 5-HT are intracellular (Blashko and Levine, 1966; Gershon, 1977; Gershon et al., 1990). Uptake into cells is therefore essential for 5-HT to be inactivated. However, 5-HT is highly charged and hydrophilic at a physiological $\mathrm{pH}$ and thus does not readily permeate plasma membranes. A mechanism to transport 5-HT into cells is thus required to metabolize 5-HT after it has been secreted, as well as to reduce the 5-HT concentration in the local environment of 5-HT receptors. The inability of epithelial cells, mast cells, and neurites of SERT $-/-$ mice to take up ${ }^{3} \mathrm{H}-5-\mathrm{HT}$ at low concentrations (20 nM) suggests that SERT is the only transporter expressed in the bowel with a high affinity for 5-HT; moreover, no other transporters are able to compensate for the loss of SERT in mediating high-affinity 5-HT transport. However, the bowel was found to express other molecules that transport 5-HT, although they lack the selectivity and affinity of SERT for 5-HT. mRNA encoding DAT, OCT-1, and OCT-3 and the corresponding immunoreactivities of the respective proteins were all found to be present in the bowels of SERT $+/+$ and SERT $-/-$ mice. DAT immunoreactivity was confined to the ENS, a 


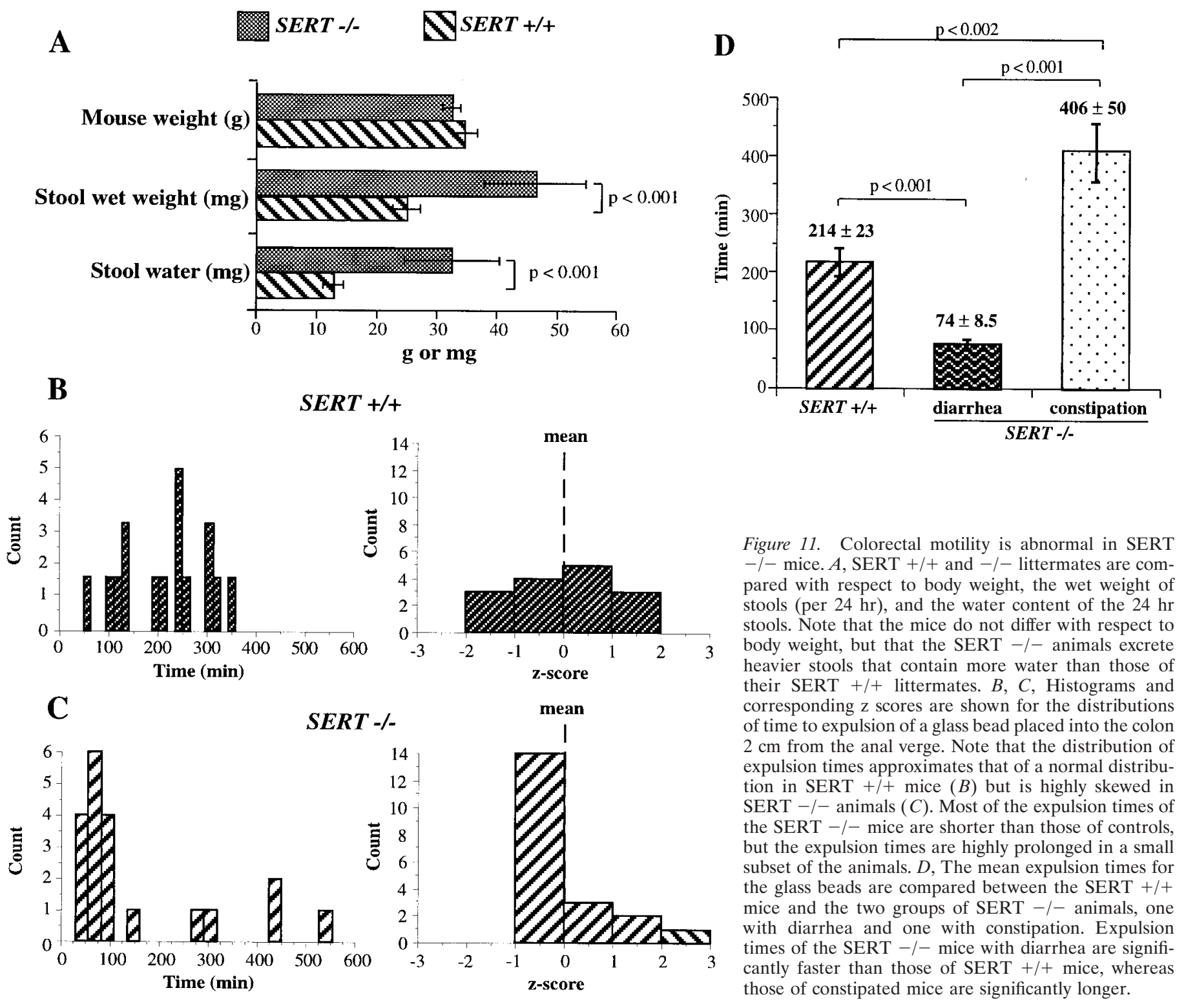

location that would enable DAT to contribute to the termination of the neurotransmitter actions of 5-HT. DAT has been shown to mediate the uptake of 5-HT by central dopaminergic neurons when 5-HT accumulates in the brains of mice that lack MAO-A (Cases et al., 1998). The immunoreactivity of OCT-1 was observed in the mucosal epithelium, as well as in the ENS; therefore, OCT-1 could contribute to inactivation of the 5-HT secreted by EC cells, mast cells, or enteric neurons. OCT-3 protein was not located, but as the extraneuronal monoamine transporter (or uptake $_{2}$ ) site (Iversen, 1967), it is known to be widely expressed in non-neuronal tissue and thus likely to be located in the intestinal mucosa. Between them, the presence of DAT and the OCTs in the SERT -/- intestine might thus compensate, at least partially, for the absence of SERT. These transporters might also prevent released 5-HT from reaching toxic concentrations and, in the absence of challenge to the bowel, allow serotonergic signaling to occur. The apparent upregulation of OCT-1 in the brains and intestines of SERT $-/-$ mice is consistent with these suggestions.

The observation that essentially no 5-HT was found in the blood of SERT -/- mice indicates that these animals efficiently prevent enteric 5-HT from reaching the circulation. Most of the 5 -HT in blood is normally contained in platelets, which lack tryptophan hydroxylase activity and do not synthesize 5-HT (Erspamer, 1966; Morrissey et al., 1977). Platelets primarily obtain 5 -HT by taking it up within the gut. EC cells constitutively secrete 5-HT (Toh, 1954; Schwörer et al., 1987b) and release more when stimulated to do so (Ahlman and Dählstrom, 1983; Grønstad et al., 1985; Schwörer et al., 1987a; Racké et al., 1988; Wingren et al., 1988; Grider et al., 1996). EC cell 5-HT can overflow to the intestinal lumen (Nilsson et al., 1987; Wingren et al., 1988), can be inactivated by uptake and metabolism within the mucosa (Gershon and Ross, 1966a; Pan and Gershon, 2000), or can reach the portal circulation (Toh, 1954; Schwörer et al., 1987b). Free 5-HT in the portal vein is taken up and metabolized in the liver (Blashko and Levine, 1966; Gershon and Ross, 1966a; Gershon, 1977). OCTs are expressed in the liver (Gründemann et al., 1994; Busch et al., 1996a, 1998; Zhang et al., 1997; Kekuda et al., 1998; Meyer-Wentrup et al., 1998; Wu et al., 1998); however, because there is virtually no 5 -HT in the blood of SERT - /- 
mice, SERT must be the only 5-HT transporter of platelets. Platelets of SERT $-/-$ mice thus are not loaded with 5-HT as they circulate through the gut. The absence of plasma 5-HT in SERT $-/-$ mice explains why the toxic effects of 5-HT are not seen in these animals and indicates that the alternative transporters that are expressed in the gut and liver must fully remove 5-HT from portal blood and prevent it from reaching the systemic circulation. It is also possible that the secretion of 5-HT in the gut is minimal in SERT -/- mice; however, the physiological and immunochemical evidence suggests that this is not the primary cause for reduced blood levels.

5-HT was found in all of its normal sites in the gut of SERT $-/-$ mice, probably because EC cells, mast cells, and serotonergic neurons synthesize 5-HT. Each of these cells contains tryptophan hydroxylase immunoreactivity (Hasegawa et al., 1989; Ekwall et al., 1998; Yu et al., 1999). mRNA encoding tryptophan hydroxylase was found in the bowels of wild-type and knock-out mice that lacked SERT and/or DAT; indeed, tryptophan hydroxylase expression was apparently upregulated in the gut of SERT -/animals, which might help them to maintain their 5-HT level. The presence of 5-HT immunoreactivity in the ENS of SERT -/mice is not compatible with the hypothesis that enteric neurons contain 5-HT only because of SERT-mediated reuptake (Meedeniya et al., 1998). Because the immunoreactivities of DAT or the OCTs are not distributed in a pattern that is similar to that of $5-\mathrm{HT}$, it is unlikely that they could be responsible for the presence of 5-HT in enteric neurons.

5-HT-immunoreactive terminal varicosities and neurites in the tertiary plexus were more abundant in SERT $-/-$ than in SERT $+/+$ animals. The intraneuronal distribution of 5-HT may thus be influenced by the retrieval of 5-HT. However, 5-HT has also been found to promote the development of enteric neurons and to enhance their extension of neurites by stimulating $5-\mathrm{HT}_{2 \mathrm{~B}}$ receptors (Fiorica-Howells et al., 2000). It is thus possible that the greater number of 5-HT-immunoreactive neurites present in the SERT -/- ENS occurs because the lack of high-affinity reuptake potentiates the trophic effects of 5-HT.

Although SERT $-/-$ mice survive and gain weight, their bowels do not function normally. The stools of SERT $-/-$ mice contained more water than those of their SERT $+/+$ littermates, and the motility of the SERT - / - distal colon was also increased. This defect may not be a serious handicap in animal quarters approved by the Association for Assessment and Accreditation of Laboratory Animal Care, because mice have access to water ad libitum; however, it might be a severe handicap in the wild. Rapid motility in the distal intestine decreases the time available for water absorption. Although the increase in colonic motility appeared in most SERT $-/-$ animals, a striking decrease in colonic motility was seen in a minority of these animals; therefore, there was a larger group of SERT -/- mice with watery diarrhea and enhanced motility and a smaller group with constipation and diminished motility. For a single SERT $-/-$ mouse, these attributes were not fixed; instead, diarrhea and constipation alternated irregularly. The diarrhea and increased motility might be attributable to the potentiation of serotonergic signaling; for example, fluoxetine, a SERT inhibitor, potentiates the peristaltic reflex in the guinea pig distal colon in vitro (Wade et al., 1996) and causes more submucosal primary afferent neurons to respond to 5-HT-releasing mucosal stimuli (Chen et al., 1998; Pan and Gershon, 2000). The watery nature of the diarrhea in SERT -/mice is also consistent with the possibility that 5-HT-mediated secretory reflexes (Sidhu and Cooke, 1995; Cooke et al., 1997) are potentiated. The desensitization of 5-HT receptors might explain the transient constipation that occurs in a minority of the SERT $-/-$ mice. Desensitization of 5-HT receptors occurs when SERT is inhibited in the guinea pig distal colon in vitro, and when this does occur, the peristaltic reflex is blocked (Wade et al., 1996). Catecholamines strongly stimulate 5-HT release from EC cells (Ahlman et al., 1976; Racké et al., 1988; Racké and Schwörer, 1991), and sympathetic nerves innervate enteric serotonergic neurons (Gershon and Sherman, 1987). Infections or fright, which causes the release of catecholamines from sympathetic nerves or the adrenal medulla, might release enough 5-HT to overcome compensatory mechanisms in the SERT $-/-$ bowel and desensitize enteric 5-HT receptors. Diarrhea and constipation frequently alternate in humans with irritable bowel syndrome (IBS) (Drossman, 1994; Talley, 1998), and this syndrome has been linked to enteric 5-HT (Bearcroft et al., 1998; Camilleri et al., 1999). Alosetron, a 5- $\mathrm{HT}_{3}$ antagonist, is strikingly effective in treating diarrhea-predominant IBS (Bardhan et al., 1996; Camilleri et al., 1999). Conceivably, a defect resulting in an excessive concentration of 5-HT reaching enteric receptors, caused by either oversecretion or, as in SERT $-/-$ mice, inadequate inactivation, might contribute to the pathogenesis of IBS.

\section{REFERENCES}

Ahlman H, Dählstrom A (1983) Vagal mechanisms controlling serotonin release from the gastrointestinal tract and pyloric motor function. J Auton Nerv Syst 9:119-140.

Ahlman H, Lundberg J, Dählstrom A, Kewenter J (1976) A possible vagal adrenergic release of serotonin from enterochromaffin cells in the cat. Acta Physiol Scand 98:366-375.

Anderson GM, Young JG, Cohen DJ, Schlicht KR, Patel N (1981) Liquid-chromatographic determination of serotonin and tryptophan in whole blood and plasma. Clin Chem 27:775-776.

Askenase PW, Bursztajn S, Gershon MD, Gershon RK (1980) T celldependent mast cell degranulation and release of serotonin in murine delayed-type hypersensitivity. J Exp Med 152:1358-1374.

Askenase PW, Van Loveren H, Kraeuter-Kops S, Ron Y, Meade R, Theoharides TC, Norlund JJ, Scovern H, Gershon MD, Ptak W (1983) Defective elicitation of delayed-type hypersensitivity in $\mathrm{W} / \mathrm{W}^{\mathrm{v}}$ and S1/S1 ${ }^{\mathrm{d}}$ mast cell-deficient mice. J Immunol 131:2687-2694.

Auerbach L (1862) Über einen Plexus myentericus, einen bisher unbekannten ganglio-nervösen Apparat im Darmkanal der Wirbeltiere. Vorläufige Mitteilung. Breslau, Germany: E. Morgenstern.

Bardhan K, Bodemar G, Geldof H, Schultz E, Snell C, Darekar B (1996) A double-blind placebo-controlled study to evaluate the efficacy of alosetron in the treatment of irritable bowel syndrome (IBS). Gastroenterology 110:A630.

Bayliss WM, Starling EH (1899) The movements and innervation of the small intestine. J Physiol (Lond) 24:99-143.

Bayliss WM, Starling EH (1900a) I. The movements and innervation of the large intestine. J Physiol (Lond) 26:107-118.

Bayliss W M, Starling EH (1900b) II. The movements and innervation of the small intestine. J Physiol (Lond) 26:125-138.

Bearcroft CP, Perrett D, Farthing MJ (1998) Postprandial plasma 5-hydroxytryptamine in diarrhoea predominant irritable bowel syndrome: a pilot study. Gut 42:42-46.

Bengel D, Murphy DL, Andrews AM, Wichems CH, Feltner D, Heils A, Mossner R, Westphal H, Lesch KP (1998) Altered brain serotonin homeostasis and locomotor insensitivity to 3,4-methylenedioxymethamphetamine ("Ecstasy") in serotonin transporter-deficient mice. Mol Pharmacol 53:649-655.

Bertrand PP, Kunze WAA, Furness JB, Bornstein JC (2000) The terminals of myenteric intrinsic primary afferent neurons of the guinea pig ileum are excited by $5-\mathrm{HT}$ acting at $5-\mathrm{HT}_{3}$ receptors. Neuroscience 101:459-469.

Blakely RD, Berson HE, Fremeau RT, Caron MG, Peek MM, Prince HK, Bradley CC (1991) Cloning and expression of a functional serotonin transporter from rat brain. Nature 354:66-70.

Blashko H, Levine WG (1966) Metabolism of indolealkylamines. In: Handbook of experimental pharmacology: 5-hydroxytryptamine and related indolealkylamines 19 (Erspamer V, ed), pp 212-244. New York: Springer.

Bülbring E, Lin RCY, Schofield G (1958) An investigation of the peristaltic reflex in relation to anatomical observations. Q J Exp Physiol 43:26-37.

Busch AE, Quester S, Ulzheimer JC, Gorboulev V, Akhoundova A, 
Waldegger S, Lang F, Koepsell H (1996a) Monoamine neurotransmitter transport mediated by the polyspecific cation transporter rOCT1. FEBS Lett 395:153-156.

Busch AE, Quester S, Ulzheimer JC, Waldegger S, Gorboulev V, Arndt P, Lang F, Koepsell H (1996b) Electrogenic properties and substrate specificity of the polyspecific rat cation transporter rOCT1. J Biol Chem 271:32599-32604.

Busch AE, Karbach U, Miska D, Gorboulev V, Akhoundova A, Volk C, Arndt P, Ulzheimer JC, Sonders MS, Baumann C, Waldegger S, Lang F, Koepsell H (1998) Human neurons express the polyspecific cation transporter hOCT2, which translocates monoamine neurotransmitters, amatadine, and memantine. Mol Pharmacol 54:342-352.

Camilleri M, Mayer EA, Drossman DA, Heath A, Dukes GE, McSorley D, Kong S, Mangel AW, Northcutt AR (1999) Improvement in pain and bowel function in female irritable bowel patients with alosetron, a $5-\mathrm{HT}_{3}$ receptor antagonist. Aliment Pharmacol Ther 13:1149-1159.

Cases O, Lebrand C, Giros B, Vitalis T, De Maeyer E, Caron MG, Price DJ, Gaspar P, Seif I (1998) Plasma membrane transporters of serotonin, dopamine, and norepinephrine mediate serotonin accumulation in atypical locations in the developing brain of monoamine oxidase A knock-outs. J Neurosci 18:6914-6927.

Chen J-X, Pan H, Rothman TP, Wade PR, Gershon MD (1998) Guinea pig 5-HT transporter: cloning, expression, distribution, and function in intestinal sensory reception. Am J Physiol 275:G433-G448.

Cooke HJ, Sidhu M, Wang Y-Z (1997) 5-HT activates neural reflexes regulating secretion in the guinea-pig colon. Neurogastroenterol Motil 9:181-186.

Costa M, Furness JB, Cuello AC, Verhofstad AAJ, Steinbusch HWJ, Elde RP (1982) Neurons with 5-hydroxytryptamine-like immunoreactivity in the enteric nervous system: their visualization and reactions to drug treatment. Neuroscience 7:351-363.

Costa M, Brookes SJH, Steele PA, Gibbins I, Burcher E, Kandiah CJ (1996) Neurochemical classification of myenteric neurons in the guinea pig ileum. Neuroscience 75:949-967.

Drossman DA (1994) Irritable bowel syndrome. Gastroenterologist 2:315-326.

Eaker EY, Bixler GB, Dunn AJ, Moreshead WV, Mathias JR (1988) Dopamine and norepinephrine in the gastrointestinal tract of mice and the effects of neurotoxins. J Pharmacol Exp Ther 244:438-442.

Ekwall O, Hedstrand H, Grimelius L, Haavik J, Perheentupa J, Gustafsson J, Husebye E, Kampe O, Rorsman F (1998) Identification of tryptophan hydroxylase as an intestinal autoantigen. Lancet 352:279-283.

Erspamer V (1966) Occurrence of indolealkylamines in nature. In: Handbook of experimental pharmacology: 5-hydroxytryptamine and related indolealkylamines 19 (Erspamer V, ed), pp 132-181. New York: Springer.

Fabre V, Beaufour C, Evrard A, Rioux A, Hanoun N, Lesch KP, Murphy DL, Lanfumey L, Hamon M, Martres MP (2000) Altered expression and functions of serotonin 5-HT1A and 5-HT1B receptors in knockout mice lacking the 5-HT transporter. Eur J Neurosci 12:2299-2310.

Fiorica-Howells E, Maroteaux L, Gershon MD (2000) Serotonin and the $5-\mathrm{HT}_{2 \mathrm{~B}}$ receptor in the development of enteric neurons. J Neurosci 20:294-305.

Fischman DA, Gershon MD (1964) A method for studying intracellular movement of water-soluble isotopes prior to radioautography. J Cell Biol 21:139-143

Foxx-Orenstein AE, Kuemmerle JF, Grider JR (1995) The peristaltic reflex induced by mucosal stimuli in human and guinea pig intestine is mediated by distinct mucosal 5-HT receptors. Gastroenterology 108:A600.

Furness JB, Costa M (1982) Neurons with 5-hydroxytryptamine-like immunoreactivity in the enteric nervous system: their projections in the guinea pig small intestine. Neuroscience 7:341-350.

Furness JB, Costa M (1987) The enteric nervous system, pp 65-69. New York: Churchill Livingstone.

Gershon MD (1977) Biochemistry and physiology of serotonergic transmission. In: Handbook of physiology: the nervous system 1 (Brookhart JM, Mountcastle VB, eds), pp 573-623. Bethesda, MD: American Physiological Society.

Gershon MD (1999) The enteric nervous system: a second brain. Hosp Pract 34:31-32, 35-38, 41-42.

Gershon MD, Altman RF (1971) An analysis of the uptake of 5-hdyroxytryptamine by the myenteric plexus of the small intestine of the guinea pig. J Pharmacol Exp Ther 179:29-41.

Gershon MD, Ross LL (1962) Studies on the relationship of 5-hydroxytryptamine and the enterochromaffin cell to anaphylactic shock in mice. J Exp Med 115:367-382.

Gershon MD, Ross LL (1966a) Radioisotopic studies of the binding, exchange, and distribution of 5-hydroxytryptamine synthesized from its radioactive precursor. J Physiol (Lond) 186:451-476.

Gershon MD, Ross LL (1966b) Location of sites of 5-hydroxytryptamine storage and metabolism by radioautography. J Physiol (Lond) 186:477-492.
Gershon MD, Sherman DL (1987) Noradrenergic innervation of serotonergic neurons in the myenteric plexus. J Comp Neurol 259:193-210.

Gershon MD, Sherman DL, Pintar JE (1990) Type-specific localization of monoamine oxidase in the enteric nervous system: relationship to 5-hydroxytryptamine, neuropeptides, and sympathetic nerves. J Comp Neurol 301:191-213.

Gershon MD, Kirchgessner AL, Wade PR (1994) Functional anatomy of the enteric nervous system. In: Physiology of the gastrointestinal tract, Ed 3 (Johnson LR, Alpers DH, Jacobson ED, Walsh JH, eds), pp 381-422. New York: Raven.

Gershon RK, Askenase P, Gershon MD (1975) Requirement for vasoactive amines for production of delayed-type hypersensitivity skin reactions. J Exp Med 142:732-747.

Giros B, el Mestikawy S, Godinot N, Zheng K, Han H, Yang-Feng T, Caron MG (1992) Cloning, pharmacological characterization, and chromosome assignment of the human dopamine transporter. Mol Pharmacol 42:383-390.

Grider JR, Kuemmerle JF, Jin JG (1996) 5-HT released by mucosal stimuli initiates peristalsis by activating 5 -HT4/5-HT1p receptors on sensory CGRP neurons. Am J Physiol 270:G778-G782.

Grider JR, Foxx-Orenstein AE, Jin JG (1998) 5-Hydroxytryptamine receptor agonists initiate the peristaltic reflex in human, rat, and guinea pig intestine. Gastroenterology 115:370-380.

Grønstad KO, DeMagistris L, Dählström A, Nilsson O, Price B, Zinner MJ, Jaffe BM, Ahlman H (1985) The effects of vagal nerve stimulation on endoluminal release of serotonin and substance $\mathrm{P}$ into the feline small intestine. Scand J Gastroenterol 20:163-169.

Gründemann D, Gorboulev V, Gambaryan S, Veyhl M, Koepsell H (1994) Drug excretion mediated by a new prototype of polyspecific transporter. Nature 372:549-552.

Gründemann D, Koster S, Kiefer N, Breidert T, Engelhardt M, Spitzenberger F, Obermuller N, Schomig E (1998) Transport of monoamine transmitters by the organic cation transporter type 2, OCT2. J Biol Chem 273:30915-30920.

Hasegawa H, Kobayashi T, Inoue F, Ichiyama A (1989) Intracellular metabolism of biogenic amines in paraneurons. Arch Histol Cytol 52:69-74.

Heath JP (1996) Epithelial cell migration in the intestine. Cell Biol Int 20:139-146.

Hoffman B, Mezey E, Brownstein M (1991) Cloning of a serotonin transporter affected by antidepressants. Science 254:579-580.

Iversen LL (1967) The uptake and storage of noradrenaline in sympathetic nerves. Cambridge, UK: Cambridge UP.

Jackson BP, Wightman RM (1995) Dynamics of 5-hydroxytryptamine released from dopamine neurons in the caudate putamen of the rat. Brain Res 674:163-166.

Jin JG, Foxx-Orenstein AE, Grider JR (1999) Propulsion in guinea pig colon induced by 5 -hydroxytruyptamine via $5-\mathrm{HT}_{4}$ and $5-\mathrm{HT}_{3}$ receptors. J Pharmacol Exp Ther 288:93-97.

Kalivas PW, Miller JS (1985) Dopamine microinjection into the nucleus accumbens: correlation between metabolism and behavior. Biochem Pharmacol 34:284-286.

Karbach U, Kricke J, Meyer-Wentrup F, Gorboulev V, Volk C, LoffingCueni D, Kaissling B, Bachmann S, Koepsell H (2000) Localization of organic cation transporters OCT1 and OCT2 in rat kidney. Am J Physiol Renal Physiol 279:F679-F687.

Kekuda R, Prasad PD, Wu X, Wang H, Fei YJ, Leibach FH, Ganapathy $\mathrm{V}$ (1998) Cloning and functional characterization of a potentialsensitive, polyspecific organic cation transporter (OCT3) most abundantly expressed in placenta. J Biol Chem 273:15971-15979.

Kirchgessner AL, Tamir H, Gershon MD (1992) Identification and stimulation by serotonin of intrinsic sensory neurons of the submucosal plexus of the guinea pig gut: activity-induced expression of Fos immunoreactivity. J Neurosci 12:235-249.

Kirchgessner AL, Liu M-T, Gershon MD (1996) In situ identification and visualization of neurons that mediate enteric and enteropancreatic reflexes. J Comp Neurol 371:270-286.

Kunze WA, Bornstein JC, Furness JB (1995) Identification of sensory nerve cells in a peripheral organ (the intestine) of a mammal. Neuroscience $66: 1-4$.

Liu K, Hsiung S, Adlersberg M, Sacktor T, Gershon M, Tamir H (2000) $\mathrm{Ca}^{2+}$-evoked serotonin secretion by parafollicular cells: roles in signal transduction of phosphatidylinositol $3^{\prime}$-kinase, and the $\mathrm{g}$ and $\mathrm{z}$ isoforms of protein kinase C. J Neurosci 20:1365-1373.

Meedeniya AC, Brookes SJ, Hennig GW, Costa M (1998) The projections of 5-hydroxytryptamine-accumulating neurones in the myenteric plexus of the small intestine of the guinea-pig. Cell Tissue Res 291:375-384.

Meissner G (1857) Über die Nerven der Darmwand. Z Ration Med 8:364-366.

Meyer-Wentrup F, Karbach U, Gorboulev V, Arndt P, Koepsell H (1998) Membrane localization of the electrogenic cation transporter rOCT1 in rat liver. Biochem Biophys Res Commun 248:673-678.

Morrissey JJ, Walker MN, Lovenberg W (1977) The absence of trypto- 
phan hydroxylase activity in blood platelets. Proc Soc Exp Biol Med $154: 496-499$.

Nilsson O, Ahlman H, Geffard M, Dahlstrom A, Ericson LE (1987) Bipolarity of duodenal enterochromaffin cells in the rat. Cell Tissue Res 248:49-54.

Osinki MA, Bass P, Gaumnitz EA (1999) Peripheral and central actions of orphanin FQ (nociceptin) on murine colon. Am J Physiol 276:G125-G131.

Pan H, Gershon MD (2000) Activation of intrinsic afferent pathways in submucosal ganglia of the guinea pig small intestine. J Neurosci 20:3295-3309.

Racké K, Schwörer H (1991) Regulation of serotonin release from the intestinal mucosa. Pharmacol Res 23:13-25.

Racké K, Schwörer H, Kilbinger H (1988) Adrenergic modulation of the release of 5-hydroxytryptamine from the vascularly perfused ileum of the guinea-pig. Br J Pharmacol 95:923-931.

Rioux A, Fabre V, Lesch KP, Moessner R, Murphy DL, Lanfumey L, Hamon M, Martres MP (1999) Adaptive changes of serotonin 5-HT2A receptors in mice lacking the serotonin transporter. Neurosci Lett 262:113-116.

Sang Q, Young H (1996) Chemical coding of neurons in the myenteric plexus and external muscle of the small and large intestine of the mouse. Cell Tissue Res 284:39-53.

Schwörer H, Racké K, Kilbinger H (1987a) Cholinergic modulation of the release of 5-hydroxtryptamine from the guinea pig ileum. Naunyn Schmiedebergs Arch Pharmacol 336:127-132.

Schwörer H, Racké K, Kilbinger H (1987b) Spontaneous release of endogenous 5-hydroxytryptamine and 5-hydroxyindoleacetic acid from the isolated vascularly perfused ileum of the guinea pig. Neuroscience 21:297-303.

Sidhu M, Cooke HJ (1995) Role for 5-HT and ACh in submucosal reflexes mediating colonic secretion. Am J Physiol 269:G346-G351.

Sora I, Wichems C, Takahashi N, Li XF, Zeng Z, Revay R, Lesch KP, Murphy DL, Uhl GR (1998) Cocaine reward models: conditioned place preference can be established in dopamine- and in serotonintransporter knockout mice. Proc Natl Acad Sci USA 95:7699-7704.

Stappenbeck TS, Wong MH, Saam JR, Mysorekar IU, Gordon JI (1998) Notes from some crypt watchers: regulation of renewal in the mouse intestinal epithelium. Curr Opin Cell Biol 10:702-709.

Stoll J, Goldman D (1991) Isolation and structural characterization of the murine tryptophan hydroxylase gene. J Neurosci Res 28:457-465.

Talley NJ (1998) Irritable bowel syndrome: disease definition and symptom description. Eur J Surg Suppl 583:24-28.

Tamir H, Theoharides TC, Gershon MD, Askenase PW (1982) Serotonin storage pools in basophil leukemia and mast cells: characterization of two types of serotonin binding protein and radioautographic analysis of the intracellular distribution of $\left[{ }^{3} \mathrm{H}\right]$ serotonin. J Cell Biol 93:638-648.
Tamir H, Liu KP, Heath M, Adlersberg M, Gershon MD (1994) Stimulus-induced secretion and vesicle acidification in serotonergic paraneurons (parafollicular cells): the role of voltage-gated $\mathrm{Ca}^{2+}$ channels. Soc Neurosci Abstr 20:1719.

Toh CC (1954) Release of 5-hydroxytryptamine (serotonin) from the dog's gastrointestinal tract. J Physiol (Lond) 126:248-254.

Trendelenburg P (1917) Physiologische und pharmakologische Versuche über die Dünndarm Peristaltick. Naunyn Schmiedebergs Arch Exp Pathol Pharmakol 81:55-129.

Tsubouchi S, Leblond CP (1979) Migration and turnover of enteroendocrine and caveolated cells in the epithelium of the descending colon, as shown by radioautography after continuous infusion of ${ }^{3} \mathrm{H}-$ thymidine into mice. Am J Anat 156:431-451.

Urakami Y, Okuda M, Mauda S, Saito H, Inui KI (1998) Functional characteristics and membrane localizations of rat multispecific organic cation transporters, OCT1 and OCT2 mediating tubular secretion of cationic drugs. J Pharmacol Exp Ther 287:800-805.

Vialli M (1966) Histology of the enterochromaffin cell system. In: Handbook of experimental pharmacology: 5-hydroxytryptamine and related indolealkylamines 19 (Erspamer V, ed), pp 1-65. New York: Springer.

Wade PR, Westfall JA (1985) Ultrastructure of enterochromaffin cells and associated neural and vascular elements in the mouse duodenum. Cell Tissue Res 241:557-563.

Wade PR, Chen J, Jaffe B, Kassem IS, Blakely RD, Gershon MD (1996) Localization and function of a 5-HT transporter in crypt epithelia of the gastrointestinal tract. J Neurosci 16:2352-2364.

Walker JK, Gainetdinov RR, Mangel AW, Caron MG, Shetzline MA (2000) Mice lacking the dopamine transporter display altered regulation of distal colonic motility. Am J Physiol Gastrointest Liver Physiol 279:G311-G318.

Wingren U, Ahlman H, Dahlström A, Enerbäck L (1988) Endoluminal secretin of serotonin and histamine into the small intestine of normal and nematode-infected rats. Biog Amines 5:297-306.

Wong MH, Stappenbeck TS, Gordon JI (1999) Living and commuting in intestinal crypts. Gastroenterology 116:208-210.

Wu X, Kekuda R, Huang W, Fei YJ, Leibach FH, Chen J, Conway SJ, Ganapathy V (1998) Identity of the organic cation transporter OCT3 as the extraneuronal monoamine transporter (uptake2) and evidence for the expression of the transporter in the brain. J Biol Chem 273:32776-32786.

Yu P-L, Fujimura M, Okumiya K, Kinoshita M, Hasegawa H, Fujimiya M (1999) Immunohistochemical localization of tryptophan hydroxylase in the human and rat gastrointestinal tract. J Comp Neurol 411:654-665.

Zhang L, Dresser MJ, Gray AT, Yost SC, Terashita S, Giocomini KM (1997) Cloning and functional expression of a human liver organic cation transporter. Mol Pharmacol 51:913-921. 